\title{
Plio-Pleistocene Continental Hydroclimate and Indian Ocean Sea Surface Temperatures at the Southeast African Margin
}

\author{
Audrey K. Taylor ${ }^{1 *}$, Melissa A. Berke ${ }^{1}$, Isla S. Castañeda ${ }^{2}$, Andreas Koutsodendris ${ }^{3}$, Hernan \\ Campos $^{3}$, Ian R. Hall ${ }^{4}$, Sidney R. Hemming ${ }^{5}$, Leah J. LeVay ${ }^{6}$, Alejandra Cartagena Sierra ${ }^{1}$, \\ Keith O'Connor ${ }^{1}$, and the Expedition 361 Scientists $^{7}$
}

${ }^{1}$ Department of Civil and Environmental Engineering and Earth Sciences, University of Notre Dame, 156 Fitzpatrick Hall, Notre Dame, IN 46556, USA

${ }^{2}$ Department of Geosciences, University of Massachusetts Amherst, 627 N Pleasant St., 233 Morrill Science Center II, Amhurst, MA, 01003 USA

${ }^{3}$ Institute of Earth Sciences, Heidelberg University, Im Neuenheimer Feld 234-236, 69120, Heidelberg, Germany

${ }^{4}$ Department of Earth Sciences, Cardiff University, Main College, Park Place, PO Box 914, Cardiff Wales CF10 3AT, United Kingdom

${ }^{5}$ Lamont-Doherty Earth Observatory, Columbia University, 61 Route 9W, Palisades, NY 10964, USA

${ }^{6}$ International Ocean Discovery Program, Texas A\&M University, College Station, TX 77845, USA

${ }^{7}$ See Supporting Information Text S1

*Corresponding author: ataylo18@nd.edu

\section{Key Points:}

- Site U1478 biomarkers record Plio-Pleistocene climate changes in southeast Africa, providing regional context for early hominin evolution.

- Indonesian Throughflow variability, the mid-Pliocene warm period, and onset of Northern Hemisphere glaciation impacted Limpopo climate.

- Hydroclimate and offshore temperatures are linked, but zonal temperature gradients and glacial variability likely also modulated rainfall.

This article has been accepted for publication and undergone full peer review but has not been through the copyediting, typesetting, pagination and proofreading process, which may lead to differences between this version and the Version of Record. Please cite this article as doi: 10.1029/2020PA004186. 


\section{Abstract}

Efforts to understand long-term Indian Ocean dynamics and land-sea linkages in southeast Africa during periods of significant global and regional climate change have been inhibited by a lack of high-resolution climate records, particularly during the Plio-Pleistocene. Here we present new biomarker and pollen records from International Ocean Discovery Program (IODP) Site U1478, located at the Upper Agulhas Confluence near the Limpopo River mouth, to establish environmental conditions at the southeast African margin between 4 and 1.8 Ma and address this spatiotemporal gap. Compound-specific hydrogen isotopes of terrestrial leaf waxes $\left(\delta \mathrm{D}_{\text {wax }}\right)$ and TEX $_{86}$, using marine archaeal lipids, document hydroclimate variability and sea surface temperatures (SST), respectively, permitting an onshore-offshore climate comparison. The U1478 records establish the Limpopo catchment response to the switch in Indonesian Throughflow source waters, the mid-Pliocene Warm Period, and intensification of Northern Hemisphere glaciations at $\sim 2.7 \mathrm{Ma}$. Broad coherence between the $\delta \mathrm{D}_{\mathrm{wax}}$ and SST records supports a linkage between Indian Ocean temperatures and southeast African hydroclimate. We hypothesize that additional mechanisms including Indian Ocean cross-basin SST gradients $(\triangle \mathrm{SST})$ and high latitude glaciation acted as hydroclimate controls during the Plio-Pleistocene. We use $\Delta$ SST to evaluate ocean-atmosphere patterns similar to the Indian Ocean Dipole (IOD) and establish generally wetter conditions in the region associated with positive IOD-like phases. Additionally, an obliquity signal evident in the $\delta \mathrm{D}_{\text {wax }}$ record indicates that glacial-interglacial variability likely influenced the tropical rain belt position and also controlled rainfall.

Hydroclimate and environmental conditions across the Plio-Pleistocene in southeast Africa may have important implications for regional hominin evolution.

Keywords: East Africa, Plio-Pleistocene, organic geochemistry, hydroclimate, sea surface temperature, Indian Ocean

\section{Introduction}

The Plio-Pleistocene encompasses large-scale changes in climate and may provide an analogue for the function of Earth's ecosystems in a high carbon dioxide $\left(\mathrm{CO}_{2}\right)$ world. Pliocene climate was characterized by atmospheric $\mathrm{CO}_{2}$ levels similar to today, reduced sea surface temperature (SST) gradients, and events such as the restriction of the Central American and 
Indonesian Seaways (Cane \& Molnar, 2001; Fedorov et al., 2013). Despite its relative warmth and stability, the Pliocene is defined by long-term cooling that is potentially related to tectonic plate movement and consequent changes in ocean currents and $p \mathrm{CO}_{2}$ drawdown, especially in the Indo-Pacific region (Cane \& Molnar, 2001). The Plio-Pleistocene transition around 2.7 Ma is marked by the breakdown of Pliocene climate conditions, as strong SST gradients between the high- and low-latitudes and across the Pacific Ocean basin were established, and Northern Hemisphere glaciation intensified (Fedorov et al., 2013). The development of stronger zonal SST gradients in the Pacific Ocean was likely related to gradual thermocline shoaling in the Pliocene and an increase in tropical upwelling that led to strengthened Walker circulation (Ravelo et al., 2004). The interaction between these ocean-atmosphere feedbacks and changes in insolation potentially magnified the climate's sensitivity to obliquity, leading to the $41 \mathrm{kyr}$ pacing of higher amplitude glacial cycles in the early Pleistocene (Ravelo et al., 2004).

In East Africa, Plio-Pleistocene records have added environmental context to our understanding of hominin evolution. Leaf wax isotopes and pollen document long-term aridification and vegetation change across the Pliocene in northeast Africa (Feakins et al., 2005; Liddy et al., 2016). As Indian Ocean SSTs are an important influence on East African hydroclimate (Tierney et al., 2013), Indian Ocean cooling related to a switch in Indonesian Throughflow source waters may have influenced moisture availability and contributed to Pliocene drying (Cane \& Molnar, 2001; Liddy et al., 2016). Shifting climatic and environmental conditions during the Pliocene potentially influenced early hominin behavior and diet, indicated by carbon isotope evidence of increased $\mathrm{C}_{4}$ plant uptake (Cerling et al., 2013) that corresponds to the expansion of $\mathrm{C}_{4}$ vegetation in northeastern Africa (Liddy et al., 2016). At the Pleistocene transition, marine records of continental dust flux document an increase in aridity and climate variability in northern Africa (deMenocal 1995, 2004) and faunal assemblages from fossil records across eastern Africa similarly demonstrate a shift to more open and arid environments with greater climate variability (e.g. Bobe et al., 2002). This climate shift to increasingly more variable conditions in the early Pleistocene is linked to early hominin evolutionary transitions and increased speciation (Maslin \& Trauth, 2009; Maslin et al., 2014).

Continuous records of Plio-Pleistocene hydroclimate and oceanographic change in southeast Africa remain sparse, despite being an important location of early hominin evolution, evidenced by early Pleistocene fossil deposits in limestone caves located within the Limpopo

This article is protected by copyright. All rights reserved. 
River catchment (Herries et al., 2020). Temperature variability of the Agulhas Current at the southeast African margin has been linked to onshore climate and environmental change that may have impacted hominins, such as vegetation fluctuations in the Limpopo River catchment for the last 2.2 Ma (Castañeda et al., 2016; Dupont et al., 2011, 2019). However, as both PlioPleistocene Indian Ocean SST and southeast African hydroclimate records are rare, controls on regional rainfall during early hominin evolution remain unclear. Comparison of records from the Limpopo catchment (the past 2.14 Ma; Caley et al., 2018) to nearby Lake Malawi (the past 1.3 Ma; Johnson et al., 2016) highlights spatial differences in southeast African precipitation and the need to better understand regional climate dynamics. While Lake Malawi became progressively wetter, the Limpopo catchment experienced long-term aridification between 1 and $0.6 \mathrm{Ma}$, indicating contrasting habitats and climatic conditions that may have been important for hominin evolution (Caley et al., 2018).

Here we present new biomarker and pollen records from sediment cores at IODP Expedition 361 Site U1478 (Hall et al., 2017), located in the southernmost Mozambique Channel at the Upper Agulhas Confluence (UAC) near the Limpopo River drainage (Figure 1). Importantly, Site U1478 spans a critical gap in paleoclimate reconstructions from southeast Africa between 4 and $1.8 \mathrm{Ma}$. We use leaf wax hydrogen isotopes $\left(\delta \mathrm{D}_{\mathrm{wax}}\right)$ and TEX ${ }_{86} \mathrm{SSTs}_{\text {to }}$ document hydroclimate and Indian Ocean variability, respectively, at the southeast African margin.

\section{Study area}

Site U1478 is located 75 nautical miles east of the Limpopo River mouth on the Inharrime Terrace in the southwest Indian Ocean $\left(25^{\circ} 49.26^{\prime} \mathrm{S}, 34^{\circ} 46.14^{\prime} \mathrm{E}\right.$; 488 meters below sea level) (Hall et al., 2017). The Inharrime Terrace lies near the convergence of the Mozambique Current (MC) and South East Madagascar Current (SEMC), which contain water transported across the Indian Ocean by the South Equatorial Current (Figure 1). The confluence of the MC and EMC forms the Agulhas Current (AC), the strongest western boundary current in the Southern Hemisphere (Lutjeharms, 2006). The AC flows southward along the African coast before retroflecting east toward the Indian Ocean (Agulhas Return Current), with some leakage of warm, saline water into the southern Atlantic that can affect thermohaline circulation (Lutjeharms, 2006) (Figure 1). Mean annual SST in the Mozambique Channel is approximately

This article is protected by copyright. All rights reserved. 
$28^{\circ} \mathrm{C}$, with an annual range of $\sim 5^{\circ} \mathrm{C}$ and $6^{\circ} \mathrm{C}$ in the open and coastal waters, respectively (Fallet et al., 2012).

The Limpopo River catchment spans approximately 410,000 $\mathrm{km}^{2}$ and encompasses portions of Botswana, Zimbabwe, South Africa, and Mozambique that are mostly comprised of land in the low-lying eastern coastal plain, but also includes high-altitude Drakensberg Escarpment and central plateau regions (Dupont et al., 2011). Mean annual temperature ranges from $16^{\circ} \mathrm{C}$ on the central plateau to $24^{\circ} \mathrm{C}$ in the lowlands (Dupont et al., 2011). The Limpopo River catchment contains five phytogeographical subregions with land cover ranging from cloud forest with evergreen, woody Podocarpus to dry scrubland and littoral dune thicket (Dupont et al., 2011). Southern Africa high elevation areas of the Great Escarpment and the Highveld are characterized by woody savannah and open grassland, respectively. Lowland vegetation near rivers in this region includes riparian and coastal forest, floodplain savannahs, herb communities, and mangroves (Dupont et al., 2011). Mean annual precipitation ranges from $600 \mathrm{~mm}$ in the lowlands to $1400 \mathrm{~mm}$ in the mountains (Boroto, 2001), and most rainfall throughout the catchment is received in the austral summer (November to March) when airflow from the southwest Indian Ocean is stronger and increased SSTs in the Agulhas Current leads to convection of warm and humid air (Jury et al., 1993; Reason \& Mulenga, 1999; Tyson \& Preston-Whyte, 2000). A summer rainfall maximum is also facilitated by the southward movement of the tropical rain belt, with the marine expression of the rain belt referred to as the Intertropical Convergence Zone (ITCZ) (Nicholson, 2018).

\section{Methods}

\subsection{Chronology and statistics}

The age model for Site U1478 is presented in Koutsodendris et al. (2020) using XRF core-scanning data tuned to the most prominent orbital signal for sections of similar sedimentation rates. Our record spans from 160.3 to $257.4 \mathrm{~m}$ cored composite depth below sea floor (CCSF) and the overall age model establishes the temporal length of this sediment interval to be between 1.8 and 4.05 Ma. For most of the record, samples integrate between $\sim 300$ and 475 years, with the exception of an interval with low sedimentation (223-240 m CCSF) where samples integrate $\sim 1050$ years. Statistical analyses of Site U1478 biomarker records were 
performed using Past 4 (Hammer et al., 2001) and R (R Core Team, 2020) for REDFIT spectral (Schulz \& Mudelsee, 2002) and wavelet analyses, respectively.

\subsection{Biomarker extraction, identification, and quantification}

We collected 255 sediment samples from IODP Site U1478 for biomarker extraction, all of which were analyzed for GDGT distributions and 243 were analyzed for $\delta \mathrm{D}_{\text {wax }}$ data. The average timestep between GDGT and leaf wax samples is $8.7 \mathrm{ka}$ and $9.3 \mathrm{ka}$, respectively. Freeze-dried, homogenized sediments were extracted using a Dionex Accelerated Solvent Extractor 350 with a mixture of 9:1 dichloromethane:methanol (DCM:MeOH, v:v). The total lipid extract was separated into neutral/polar lipids, fatty acids, and phospholipid fatty acids using a $\mathrm{NH}_{2}$ gel column with 2:1 DCM:2-propanol, $4 \%$ glacial acetic acid in ethyl ether, and $\mathrm{MeOH}$, respectively. The neutral/polar fraction was further separated using alumina oxide column chromatography, isolating GDGTs using 1:1 DCM:MeOH. The fatty acid fraction was methylated by adding $3 \% \mathrm{BF}_{3}$ in $\mathrm{MeOH}$ and heating samples at $100^{\circ} \mathrm{C}$ for 2 hours. $\mathrm{A} 5 \% \mathrm{NaCl}$ solution was added to each sample after heating, and fatty acid methyl esters (FAMEs) were extracted with hexane. The resultant extract was run through $\mathrm{Na}_{2} \mathrm{SO}_{4}$ to remove any residual water. Methylated samples were further purified using silica gel column chromatography with hexane and DCM as the eluting solvents for any contaminants and FAMEs, respectively.

A Thermo Trace Ultra ISQ gas chromatograph (GC) with mass spectrometer (MS) and flame ionization detection (FID) was used to identify and quantify FAMEs, respectively. Samples were injected in splitless mode at $300^{\circ} \mathrm{C}$ onto a $30 \mathrm{~m}$ fused silica column (Agilent $\mathrm{J} \& \mathrm{~W}$ DB-5, $0.25 \mathrm{~mm}$ ID, $0.25 \mu \mathrm{m}$ film thickness) with hydrogen as the carrier gas. Following a 1minute hold at $80^{\circ} \mathrm{C}$, the $\mathrm{GC}$ oven temperature ramped to $320^{\circ} \mathrm{C}$ at a rate of $13^{\circ} \mathrm{C} \mathrm{min}^{-1}$ and with a final hold of 20 minutes. FAMEs were identified by retention times of a standard FAME mix and through comparison of fragmentation patterns in an MS library. FAMEs were quantified through comparison to the FID peak area of an internal standard, $5 \alpha$-androstane, that was added to each sample prior to analysis.

\subsection{Compound-specific $\delta \mathrm{D}$ analysis}

We analyzed $\delta \mathrm{D}$ values of the most abundant fatty acid homologue, $n-\mathrm{C}_{28}$, which is frequently used for East African $\delta$ D hydroclimate reconstructions (e.g. Tierney et al., 2008;

This article is protected by copyright. All rights reserved. 
Berke et al., 2012; Liddy et al., 2016). The $\delta D_{\text {wax }}$ values of 243 samples from Site U1478 were determined using a Trace 1310 GC coupled to a Finnigan Delta V Plus isotope ratio mass spectrometer (IRMS). Injection conditions and the GC column were identical to the GC-FID, but the oven program was as follows: $60^{\circ} \mathrm{C}$ isothermal for one minute, ramp to $320^{\circ} \mathrm{C}$ at $6^{\circ} \mathrm{C} \mathrm{min}^{-1}$, and a 12-minute isothermal at $320^{\circ} \mathrm{C}$. Data was normalized to the Vienna Standard Mean Ocean Water (VSMOW) scale using an A6 n-alkane standard mix (Arndt Schimmelmann) that was injected throughout every run for calibration purposes. Instrumental accuracy and precision were assessed using squalane (co-injected with each sample) and an in-house $n$-alkane suite, which included only $n-\mathrm{C}_{29}$ and $n$ - $\mathrm{C}_{31}$, similarly injected throughout the run. Standard deviations were generally $<3 \%$ (squalane), and $<4 \%$ ( $n$-alkane suite) within each run. The $\mathrm{H}_{3}{ }^{+}$factor was monitored daily and deemed acceptable for sample analysis with measurement standard deviations of $<0.4$. The $\mathrm{H}_{3}{ }^{+}$factor ranged between 4.4 and 6.2 throughout the course of analysis. All samples were run in duplicate with standard deviations of $<4 \%$. The $\delta \mathrm{D}_{\text {wax }}$ values are presented as the average of replicate measurements.

We corrected for the $\delta \mathrm{D}$ value of methyl group additions following methylation of a phthalic acid standard of known isotopic value. The isotopic compositions of the resultant esterified phthalic acids for each methylation batch were determined using GC-IRMS. These values were incorporated into a mass balance equation with the known standard $\delta \mathrm{D}$ value to determine and correct $\delta \mathrm{D}_{\text {wax }}$ values.

We correct for isotopic variability due to ice volume changes through time following the approach of prior studies (e.g., Berke et al., 2012; Konecky et al., 2011). We used the Lisiecki \& Raymo (2005) benthic $\delta^{18} \mathrm{O}$ stack to determine the isotopic difference of $\delta^{18} \mathrm{O}$ values from modern values for each data point. We then converted the benthic $\delta^{18} \mathrm{O}$ stack to $\delta \mathrm{D}$ and corrected $\delta \mathrm{D}_{\mathrm{wax}}$ for the determined difference.

\subsection{GDGTs}

The polar fractions containing GDGTs were filtered through a $0.45 \mu \mathrm{m}$ Teflon syringe and dissolved in 99:1 hexane: isopropanol for analysis on an Agilent 1260 series highperformance liquid chromatography (HPLC) coupled to an Agilent 6120 single quadrupole mass detector. Chromatographic conditions were set according to Hopmans et al. (2016). Briefly, two UHPLC silica columns $(2.1 \times 150 \mathrm{~mm}, 1.7 \mu \mathrm{m}$, Waters $)$ were used in series at $30^{\circ} \mathrm{C}$ with a flow

This article is protected by copyright. All rights reserved. 
rate of $0.2 \mathrm{~mL} / \mathrm{min}$. Using solvents A (hexane) and B (9:1 hexane:isopropanol), GDGTs were eluted for 25 minutes with $18 \% \mathrm{~B}$, followed by a 25 min linear increase to $35 \% \mathrm{~B}$, and finally a 30 minute linear increase to $100 \% \mathrm{~B}$.

TEX $_{86}$ values (Eq. 1) use the distribution of membrane lipids produced by mesophilic Thaumarchaeota, isoprenoid GDGTs with 1-3 cyclopentyl moieties and the crenarchaeol regioisomer (cren'), to quantify past temperatures (Schouten et al., 2002).

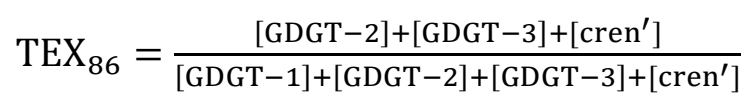

TEX $_{86}$ values were calibrated to SSTs using BAYSPAR (prior_std=20), a Bayesian, spatially varying regression model (Tierney \& Tingley, 2014; 2015). The median SST values determined with BAYSPAR are used for paleoclimate interpretations, with the full calibration range and alternate calibration (Kim et al., 2010) presented in Supplementary Information (Figures S1, S2). We use the BAYSPAR surface, rather than subsurface, temperature calibration to reconstruct Site U1478 temperatures because previous research has shown that core-top and sediment trap $\mathrm{TEX}_{86}$ derived temperatures in the Mozambique Channel are close approximations of mean annual SSTs (Fallet et al., 2011, 2012). Other reconstructions of past temperature using TEX $_{86}$ in the southwest Indian Ocean (e.g. Schefuß et al., 2011) similarly interpret an uppermost water column export signal. For comparison to Site U1478 SSTs, we use BAYSPAR calibrated TEX $_{86}$ values (Tierney \& Tingley, 2014, 2015) from IODP Site U1463 (Smith et al., 2020) and from Deep Sea Drilling Project (DSDP) Site 231 (Liddy et al., 2016) (Figure 1b). We additionally convert $\mathrm{Mg} / \mathrm{Ca}$ ratios from planktonic foraminifera at ODP Site 763A (Karas et al., 2011) to SST, using the multispecies calibration provided by Anand et al. (2003), for comparison to Site U1478.

We assess secondary effects on Site $\mathrm{U}_{1478} \mathrm{TEX}_{86}$ values using several GDGT indices. The Branched and Isoprenoid Tetraether (BIT) index (Eq. 2) is used to examine relative soil organic matter inputs to marine sediments, which may bias TEX 86 derived SSTs. The BIT index uses the abundance of branched GDGTs (I, II, II) relative to the abundance of marine crenarchaeol (cren) (Hopmans et al., 2004).

$$
\mathrm{BIT}=\frac{[\text { brGDGT }-\mathrm{I}]+[\text { brGDGT }-\mathrm{II}]+[\text { brGDGT }-\mathrm{III}]}{[\text { brGDGT }-\mathrm{I}]+[\mathrm{brGDGT}-\mathrm{II}]+[\text { brGDGT }-\mathrm{III}]+[\mathrm{cren}]}
$$


We additionally evaluate the Methane Index (MI; Zhang et al., 2011) (Eq. 3), the \% abundance of GDGT-0 relative to crenarchaeol (\%GDGT-0; Sinninghe Damsté et al., 2012; Inglis et al., 2015), and GDGT-2/GDGT-3 (Taylor et al., 2013) to determine the potential TEX 86 influence of non-thermal processes such as methanotroph and methanogen inputs and depth of GDGT export. The MI can be used to assess gas hydrate related anaerobic oxidation (AOM) of methane by methanotrophic archaea and their sedimentary contributions of GDGT-1, -2, and -3 (Inglis et al., 2015; Zhang et al., 2011). MI values exceeding 0.5 are thought to indicate a high relative input of methanotrophs and gas hydrate related AOM.

$\mathrm{MI}=\frac{[\mathrm{GDGT}-1]+[\mathrm{GDGT}-2]+[\mathrm{GDGT}-3]}{[\mathrm{GDGT}-1]+[\mathrm{GDGT}-2]+[\mathrm{GDGT}-3]+[\mathrm{cren}]+\left[\mathrm{cren}^{\prime}\right]}$

To evaluate methanogen input, which can contribute GDGT-0 and, to a lesser extent, GDGT-1, 2, and -3 (Weijers et al., 2006), we use \%GDGT-0. Values greater than $67 \%$ may indicate a considerable methanogen input and a non-thermal TEX 86 bias (Inglis et al., 2015; Sinninghe Damsté et al., 2012). The GDGT-2/GDGT-3 ratio can be used to assess changes in GDGT export depth, as GDGT-2/GDGT-3 has been shown to increase with water column depth (Hurley et al., 2018; Taylor et al., 2013).

\subsection{Palynology}

A total of 31 samples were analyzed from the core interval $257 \mathrm{~m}$ to $197 \mathrm{~m} \mathrm{CCSF}$ at orbital-scale resolution. These samples span from 4-2.2 Ma and have an average timestep of $61.4 \mathrm{ka}$. Per sample, $20 \mathrm{~g}$ of dry sediment were processed following standard palynological techniques including spiking with Lycopodium clavatum marker spores (Batch No. 3862 [9666 \pm 671 spores/tablet]), oven drying at $50^{\circ} \mathrm{C}$, treatment with $\mathrm{HCl}(20 \%), \mathrm{HF}(38 \%)$, and sieving through a $10 \mu \mathrm{m}$ mesh. Whenever possible, a minimum of 150 pollen grains and fern spores were counted per sample (average 198; range: 61-338).

This article is protected by copyright. All rights reserved. 


\section{Results}

\subsection{Hydroclimate and SSTs}

4.1.1 The $\delta \mathrm{D}_{\mathrm{wax}}$ record of hydroclimate

The hydrogen from rainfall is incorporated into terrestrial plant epicuticular waxes, resulting in a demonstrable correlation between terrestrial plant $\delta \mathrm{D}_{\text {wax }}$ and precipitation $\delta \mathrm{D}$ values (e.g. Huang et al., 2004; Sachse et al., 2004), despite an offset in $\delta \mathrm{D}_{\text {wax }}$ due to isotopic fractionations from biosynthesis and evaporative processes. In the tropics, there is a strong relationship between $\delta \mathrm{D}$ values and precipitation amount (Dansgaard, 1964; Rozanski et al., 1993), and plant waxes from southern Africa predominantly record the $\delta \mathrm{D}$ values of their source waters (Griepentrog et al., 2019; Herrmann et al., 2017). As such, we interpret more positive (negative) values to indicate more (less) arid conditions due to tropical rainfall amount.

The $\mathrm{U} 1478 \delta \mathrm{D}_{\mathrm{wax}}$ record fluctuates between $-141.7 \%$ and $-113.3 \%$ and illustrates multimillennial scale variability, with no overall drying trend across the Plio-Pleistocene (Figure 2). The mid-Pliocene (4-3.1 Ma) is characterized by more positive $\delta \mathrm{D}_{\text {wax }}$ values, indicating arid conditions. Some higher-amplitude variability begins at $\sim 3.5 \mathrm{Ma}$, and there is a notable increase in wetter conditions indicated by variable but progressively more negative $\delta \mathrm{D}_{\text {wax }}$ values between $\sim 3.3$ and $2.8 \mathrm{Ma}$ (Figure 2). Some relatively large fluctuations in $\delta \mathrm{D}_{\mathrm{wax}}$ values occur between $\sim 2.8$ and $2.1 \mathrm{Ma}$, but an overall $\sim 19 \%$ o increase in $\delta \mathrm{D}_{\text {wax }}$ indicates increasing aridity during this time (Figure 2). The early Pleistocene (2.1-1.8 Ma) is defined by a gradual increase in wetter conditions, evidenced by a $\sim 23 \%$ o decrease in $\delta \mathrm{D}_{\text {wax }}$ values (Figure 2 ).

\subsubsection{TEX $_{86}$ SSTs}

$\mathrm{TEX}_{86}$ SSTs for Site U1478 range between $24.4^{\circ} \mathrm{C}$ and $33.1^{\circ} \mathrm{C}$ and show a trend toward progressively cooler conditions at the UAC throughout much of the record, with the exceptions of general increases during 3.2-2.9 Ma, 2.3-2.1 Ma, and 2.0-1.8 Ma (Figure 2). Between 4 and 3.7 Ma, SSTs average $29.7^{\circ} \mathrm{C}$ and are relatively high, but with some abrupt excursions at 4.0 and 3.8 Ma. Between 3.7 and 3.2 Ma, SSTs gradually decrease by $\sim 3.2^{\circ} \mathrm{C}$ and subsequent progressive increasing temperatures between 3.2 and 3 Ma exhibits low amplitude variability. Beginning at $\sim 2.8 \mathrm{Ma}$, the transition into the Pleistocene is marked by a long-term SST decrease from $29^{\circ} \mathrm{C}$ to $25.7^{\circ} \mathrm{C}$, followed by an early Pleistocene SST increase between 2.3 and $1.8 \mathrm{Ma}$ (Figure 2).

This article is protected by copyright. All rights reserved. 


\subsubsection{Spectral and wavelet analyses}

The REDFIT spectral and wavelet analyses of U1478 $\delta \mathrm{D}_{\text {wax }}$ and SSTs indicate differing orbital controls throughout parts of the record. Spectral analysis of $\delta \mathrm{D}_{\text {wax }}$ illustrates significant frequencies $(\mathrm{p}<0.01)$ corresponding to obliquity and eccentricity, and no strong precession signal (Figure S3). Spectral analysis of SSTs shows only a significant $\sim 75$ ka cycle $(\mathrm{p}<0.05)$ (Figure S3). The apparent absence of a precession signal in these spectral analyses could be the result of inadequate sampling resolution. Wavelet analyses reveal more similarities between $\delta \mathrm{D}_{\text {wax }}$ and SSTs, with comparable precession ( 20 ka) and obliquity ( 40 ka) periodicities at 3.7 Ma and between 2.9 and $1.8 \mathrm{Ma}$ (Figure S4). Notably, however, the SST wavelet does not display cyclic behavior between $\sim 3.3$ and $2.9 \mathrm{Ma}$, and the $\delta \mathrm{D}_{\text {wax }}$ wavelet illustrates a more continuous period corresponding to eccentricity (100 ka) (Figure S4).

\subsection{GDGT indices}

Site U1478 BIT values range from 0.005 to 0.286 and are $\sim 0.1$ on average (Figure 2). As values $>0.3$ can indicate soil input biases (Weijers et al., 2006), low values at Site U1478 confirm a predominantly marine source of GDGTs that supports the use of TEX 86 for SST reconstruction at the southeast African margin. The BIT index and XRF-based $\log (\mathrm{Ti} / \mathrm{Ca})$ records of terrestrial influence at Site U1478 (Koutsodendris et al., 2020) show overall coherence, especially from 3.4-2.7 Ma. High (low) $\log (\mathrm{Ti} / \mathrm{Ca}$ ) values are interpreted to represent increased (decreased) fluvial sediment contributions, as Ti input is attributed to detrital material and $\mathrm{Ca}$ input is characteristic of marine biological processes (Koutsodendris et al., 2020). The consistent trends between the BIT index and $\log (\mathrm{Ti} / \mathrm{Ca})$ records, and similarity of both proxies to the $\delta \mathrm{D}_{\text {wax }}$ hydroclimate record (Figure 2), suggest a likely hydroclimate control on terrigenous delivery to Site U1478.

Additional GDGT indices further support a primarily thermal control on TEX 86 values. At Site U1478, the average MI value is 0.24 and nearly all values are $<0.3$. Only one value reaches 0.5 (Figure S5), indicating that overall, methanotroph biases of $\mathrm{TEX}_{86}$ are unlikely. Site U1478 \%GDGT-0 values do not suggest a substantial methanogenic source of GDGTs, as the average value is $32.5 \%$ and only one datapoint exceeds the $67 \%$ threshold (Figure S5). Changes in export depth can also contribute to variable $\mathrm{TEX}_{86}$ values that may be wrongly interpreted as changes in 
SST. At Site U1478, GDGT-2/GDGT-3 values range from 2.5 to 6.4 (Figure S5), reflecting consistent GDGT export from the upper water column and reinforcing our interpretation of $\mathrm{TEX}_{86}$ as a surface, rather than subsurface, temperature signal.

\subsection{Pollen}

The Plio-Pleistocene pollen assemblage is primarily composed of Cyperaceae and Poaceae with smaller contributions from Podocarpus, Asteraceae, Buxus sp., and Ericaceae (Figure 3). The percentage of Cyperaceae (sedges) shows a generally inverse trend to SST across the record, with the maximum abundance corresponding to low SSTs in the early Pleistocene (2.5-2.0 Ma) (Figure 3). The most significant increase in Poaceae (grasses) abundance, $>20 \%$ from $\sim 4.0-3.7 \mathrm{Ma}$, corresponds to an interval of decreasing, but record high SSTs and somewhat stable $\delta \mathrm{D}_{\text {wax }}$ values (Figure 3). Asteraceae (flowering plants) abundances fluctuate between $\sim 2 \%$ and $\sim 25 \%$, with the most significant increase occurring prior to the increase in SST and wetter conditions at $3.25 \mathrm{Ma}$. Podocarpus (forest taxa) abundances remain below $10 \%$ but increase from 3.1-3.0 Ma and 2.7-2.5 Ma, corresponding to intervals of cooler, transitional SSTs and reduced aridity (Figure 3). The relative abundance of Buxus sp. is $<12 \%$ and appears to increase during warmer and wetter intervals, such as between 3.2 and $2.9 \mathrm{Ma}$, and decreases significantly during the period of cooling and drying at the Plio-Pleistocene transition (Figure 3). Ericaceae (herbs and shrubs) abundances show no strong coherence with SST or $\delta \mathrm{D}_{\text {wax }}$ trends. These results show similarities to assemblages determined by Dupont et al. $(2011,2019)$ for the past $2.2 \mathrm{Ma}$ in the Limpopo region, with Cyperaceae and Poaceae as glacial and interglacial taxa, respectively, and Podocarpus as an intermediate endmember supported by relatively mild conditions. Dupont et al. (2019) demonstrate that early Pleistocene (2.2-1.8 Ma) vegetation in the Limpopo region was characterized by higher abundances of shrubland taxa and reduced mountain forest compared to later in the Pleistocene. A comparable distribution of taxa at Site U1478 suggests these conditions were persistent through the mid-Pliocene and early Pleistocene. In combination, pollen composition and the relationship between SSTs and taxa abundance corroborate a primarily Limpopo catchment signal at Site U1478.

This article is protected by copyright. All rights reserved. 


\section{Discussion}

\subsection{Biomarker evaluation}

As circulation in the Mozambique Channel is characterized by strong bottom currents and the periodic southward migration of meso-scale eddies, biomarker transport and the depositional setting near Site U1478 require some consideration for proxy interpretation. Compared to inorganic particles, uncompacted organic carbon can sink more slowly through the water column and may be more susceptible to lateral transport and advection processes. Bioturbation and downcore mixing can additionally contribute pre-aged organic material that homogenizes biomarker proxy signals and potentially decouples organic and inorganic climate records. Despite these processes, a comparison of flux-weighted foraminiferal $\left(\mathrm{Mg} / \mathrm{Ca}\right.$ and $\left.\delta^{18} \mathrm{O}\right)$ and biomarker $\left(\mathrm{TEX}_{86}\right.$ and $\mathrm{U}_{37}^{\mathrm{k} \prime}$ ) derived SSTs from sediment traps in the Mozambique Channel indicates that both inorganic and organic proxies reliably reflect mean annual SSTs (Fallet et al., 2011). In contrast to foraminiferal proxies, the SSTs derived from sediment trap biomarkers did not display seasonal variability, likely indicating lateral transport of organic carbon but over relatively short distances (Fallet et al., 2011). Additionally, Fallet et al. (2012) determined through radiocarbon dating that total organic carbon (TOC) is slightly younger than foraminiferal calcite in core tops, suggesting that biomarkers and coarser inorganic particles are similarly mixed by bioturbation, and lateral transport is not primarily responsible for age offsets between organic and inorganic proxies. However, because biomarker derived SSTs from sediment traps and older core top material are similar, the organic proxy signal is likely more homogenized as a result of fine sediment transport (Fallet et al., 2012). Hahn et al. (2018) demonstrate that even with potential homogenization and lateral transport, a combination of inorganic and organic proxies in Mozambique Channel sediments, including leaf wax biomarkers and pollen, record climate and vegetation gradients across southeast Africa. We therefore interpret Site U1478 proxy records, including biomarkers, pollen, and elemental data, to reliably reflect climate signals from within the Limpopo River catchment.

\subsection{Plio-Pleistocene climate change}

\subsubsection{Indonesian Throughflow variability}

The tectonically induced reorganization of the ITF likely occurred between 5 and $3 \mathrm{Ma}$, with many records from the eastern Indian Ocean suggesting a transition to cooler and less saline

This article is protected by copyright. All rights reserved. 
conditions linked to flow constriction and the switching of Pacific source waters sometime between 3.5 and 2.95 Ma (e.g. Karas et al., 2011). More recent studies that have extended into the Pleistocene provide evidence for later major steps in ITF constriction (Petrick et al., 2019; Smith et al., 2020). At Site U1478 we observe a significant, but gradual $\sim 3^{\circ} \mathrm{C}$ SST decrease from $\sim 3.7$ to 3.2 Ma that is synchronous and similar in magnitude to SST decreases at ODP Site 763A (Karas et al., 2011) that is proximal to the Indonesian Gateway, likely recording ITF variability (Figure 4). Another record near the ITF outflow, IODP Site U1463 (Figures 1b, 4), shows stepwise cooling across portions of this interval, interpreted as relatively minor ITF constriction during the Pliocene (Smith et al., 2020). The apparent ITF signal in Site U1478 SSTs may be linked to the relatively strong SEMC influence at this location, which receives SEC water from the eastern Indian Ocean (Figure 1).

The transition to cooler conditions beginning $~ 3.7$ Ma appears to have influenced vegetation, with an $\sim 18 \%$ increase in Cyperaceae and declining grassland (Figure 3). These changes correspond to a subtle increase in the amplitude of hydroclimate variability and a slight progression toward more positive $\delta \mathrm{D}_{\text {wax }}$ values lasting until $3.3 \mathrm{Ma}$, when there is a gradual increase in wetter conditions (Figure 2). Cane \& Molnar (2001) hypothesized that the change in ITF source and associated Indian Ocean cooling contributed to East African aridification at approximately 4-3 Ma. Concurrent subsurface water cooling and drying are apparent in northeast Africa during this period, corroborating a potential ITF control on hydroclimate in the northwestern Indian Ocean (Figure 4; Liddy et al., 2016). However, we document a more complex hydroclimate history in southeast Africa during hypothesized ITF changes perhaps due to the influence of glacial-interglacial variability or large-scale ocean and atmospheric circulation patterns operating across the Indian Ocean between 3.7 and $3.3 \mathrm{Ma}$, discussed in greater detail in section 5.4 .

\subsubsection{Mid-Pliocene Warm Period (mPWP)}

The mPWP ( 3.3-3.0 Ma) is characterized by globally increased land surface temperature $\left(>3^{\circ} \mathrm{C}\right)$ and SSTs, an enhanced hydrologic cycle, and high sea level stands as a consequence of ice sheet retreat (Dowsett et al., 2016). As the high $\mathrm{CO}_{2}$ concentrations and globally warmer conditions of the mPWP are likely analogous to future climate, there have been extensive coordinated efforts to integrate proxy data and numerical modeling to improve and

This article is protected by copyright. All rights reserved. 
assess the predictive power of climate models (Haywood et al., 2016). Southeast Africa is a notable geographic gap for both marine (McClymont et al. 2020) and terrestrial (Zhao et al. 2020) paleoenvironmental data in these proxy-model comparisons for the mPWP. The U1478 record illustrates initially cooler conditions during the mPWP (Figure 2), which may be due to changes in the Indonesian Throughflow. Other temperature records in the Indian Ocean also illustrate relatively cool conditions with no evident increase in SSTs throughout the mPWP (Figure 4). However, a clear and gradual warming trend at Site U1478 is apparent between $~ 3.2$ and 2.9 Ma that is absent in other Indian Ocean records for this period (Figure 4). This increase in SSTs at the UAC towards the end of the MPWP coincides with a similarly gradual onshore increase in precipitation, mainly after $3.1 \mathrm{Ma}$ (Figure 2). SSTs increase by $\sim 2.2^{\circ} \mathrm{C}$ between $\sim 3.2$ and 2.9 Ma and the maximum SST reached $\left(29.9^{\circ} \mathrm{C}\right)$ is $\sim 2^{\circ} \mathrm{C}$ higher than modern SSTs in the Mozambique Channel. This corresponds well with results from the Pliocene Model Intercomparison Project (PlioMIP), which estimates SST anomalies of approximately $1-2^{\circ} \mathrm{C}$ in the southwest Indian Ocean during the mPWP (Haywood et al., 2016). mPWP vegetation cover is characterized by declining Cyperaceae and reduced grassland extent, with increases in more minor landscape components such as Podocarpus in the latter portion of the mPWP during the SST transition to warmer conditions (Figure 3). This period corresponds to the likely appearance of Australopithecus africanus in southern Africa (Herries et al., 2013). Our Site U1478 preliminary pollen data corroborate fossil wood evidence suggesting this early hominid existed in a more forested and mesic habitat (Bamford, 1999).

Within the mPWP, Site U1478 also records the Marine Isotope Stage (MIS) M2 and KM2 glacials. The M2 glacial ( 3.31 - 3.26) was a standout interval that punctuated Pliocene warmth (Lisiecki \& Raymo, 2005). The intense glaciation has been previously attributed to the climate system's failed transition to more severe and frequent ice sheet expansion in the Northern Hemisphere (Haug and Tiedemann, 1998), unsuccessful in part due to high $\mathrm{CO}_{2}$ concentrations. At Site U1478, we observe a relatively sharp $\sim 2^{\circ} \mathrm{C}$ decrease in SSTs at $3.3 \mathrm{Ma}$ and a corresponding $8 \%$ increase in Cyperaceae (Figure 3). More positive $\delta \mathrm{D}_{\text {wax }}$ values at $3.3 \mathrm{Ma}$ additionally illustrate Limpopo aridity associated with M2 glacial conditions (Figure 2). Similar drying is indicated during the KM2 at 3.1 Ma (Figure 3), although SSTs remain low and with no clear decline at the UAC (Figure 2). Hydroclimate is otherwise characterized by reduced aridity

This article is protected by copyright. All rights reserved. 
during the mPWP, and these glacial events contributed to notably drier conditions in the Limpopo region (Figure 1).

\subsubsection{Onset of intensified Northern Hemisphere glaciation}

Many east African records indicate the onset of long-term drying as NHG intensified (e.g. deMenocal 1995, 2004; Bobe et al., 2002), but the period from 2.7-2.5 Ma is also characterized by the presence of large, deep lakes, indicating alternating periods of extreme wet and dry conditions (Maslin \& Trauth 2009; Maslin et al., 2014 and references therein). Site U1478 illustrates the southeast African margin response to intensified glacial-interglacial cycles with apparent cooling and drying (Figure 2). SSTs decrease by $3.6^{\circ} \mathrm{C}$ between 2.8 and $2.2 \mathrm{Ma}$ and reach a record low of $24.4^{\circ} \mathrm{C}$ around $2.5 \mathrm{Ma}$, coinciding with similarly cool excursions across the tropical oceans, including in the Arabian Sea (Herbert et al., 2010). The SST decrease associated with NHG is not monotonic, however, and excursions to higher SSTs are also apparent, including just prior to the low SSTs at 2.5 Ma (Figure 2). More arid conditions associated with the intensified NHG are indicated by an $18 \%$ increase in $\delta \mathrm{D}_{\text {wax }}$ values between 2.8 and $2.2 \mathrm{Ma}$, but the drying is also not monotonic, and some notably wetter periods punctuate the Plio-Pleistocene transition, such as at $\sim 2.5 \mathrm{Ma}$ (Figure 2). Overall cooler and drier conditions at the Plio-Pleistocene transition coincide with increases in taxa that are more typical during glacials (Dupont et al., 2011, 2019). Cyperaceae reaches maximum relative abundance as SSTs decline and both Buxus sp. and Podocarpus forest retreat (Figure 3), likely a result of increased aridity as glacial conditions developed.

\subsection{East Africa climate comparison}

Similarities in long-term climate trends have been established between north and equatorial east Africa for the Plio-Pleistocene. Continental dust flux records (deMenocal 1995, 2004), paleosol and leaf wax isotopes (Cerling et al., 2011; Feakins et al., 2005; Liddy et al., 2016), and faunal fossil records (Bobe et al., 2002) indicate a widespread cooling of North and East Africa during the Plio-Pleistocene, with often contemporaneous changes to arid, open, and more variable environments at the onset of intensified NHG ( 2.7 Ma). Liddy et al. (2016) present biomarker and pollen evidence of Pliocene climate in northeast Africa from 5.3 to $2 \mathrm{Ma}$ (DSDP Site 231; Figures1b, 4, 5), demonstrating warmer and wetter early Pliocene conditions

This article is protected by copyright. All rights reserved. 
that supported semi-arid $\mathrm{C}_{4}$ grasslands and a relatively large shift to a drier climate beginning at 4.3 Ma. The DSDP $231 \delta \mathrm{D}_{\text {wax }}$ record that overlaps with Site U1478, beginning at $\sim 4 \mathrm{Ma}$, has a similar range of $\delta \mathrm{D}_{\text {wax }}$ values, but illustrates some dissimilar hydroclimate patterns. Proxy evidence from DSDP 231 indicates long-term drying and grassland expansion between 3.5 and 2.7 Ma. Although smaller in magnitude compared to earlier Pliocene changes in northeastern Africa (Liddy et al., 2016), this gradual trend toward increased aridity is not apparent at Site U1478 and Poaceae abundances decline throughout much of the Pliocene (Figure 5). Notably, DSDP Site 231 lacks a clear drying response to the onset of NHG (Liddy et al., 2016), unlike Site U1478 and other climate records from east Africa (e.g. deMenocal 1995, 2004), but arid conditions relative to the early Pliocene are evident (Liddy et al., 2016; Figure 5).

Comparison of East African leaf wax isotope records across the Plio-Pleistocene transition suggests a broader coherence between northern and equatorial East Africa compared to the $\mathrm{U} 1478$ records. Lupien et al. (in press) also present $\delta^{13} \mathrm{C}_{\mathrm{wax}}$ evidence of $\mathrm{C}_{3} / \mathrm{C}_{4}$ vegetation change in equatorial East Africa from the Baringo-Tugen-Barsemoi (BTB) drill core in Kenya (Figure 1b) during the Plio-Pleistocene transition (3.3-2.6 Ma), with large oscillations in $\mathrm{C}_{3}$ plant inputs and a shift to increased $\mathrm{C}_{4}$ grassland extent around 3.0 Ma. Together, the BTB drill core (Lupien et al., in press) and DSDP 231 (Liddy et al., 2016) suggest wetter conditions in the Pliocene followed by gradual aridification that is punctuated by an abrupt episode of aridity and $\mathrm{C}_{4}$ grassland expansion at 3.0 Ma (Figure 5). In contrast, $\delta \mathrm{D}_{\text {wax }}$ from site $\mathrm{U} 1478$ displays less change in mean hydroclimate state from 3.3-2.6 Ma with relatively stable Cyperaceae abundances and an increase in wetter conditions at 3.0 Ma that is accompanied by increased Podocarpus (Figure 3). Pollen from Site U1478 further indicates comparatively small changes in Poaceae grassland extent from 3.3-2.6 Ma (Figure 3), whereas changes in $\delta^{13} \mathrm{C}_{\mathrm{wax}}$ in equatorial Africa indicate high-amplitude variability in $\mathrm{C}_{3}$ plant coverage (Lupien et al., in press). The climate and environmental evolution of southeast Africa at the onset of NHG is thus comparable to central and northern East Africa in that cooler, drier, and more open ecosystems are evident. However, the magnitude of long-term aridification seen at U1478 between 4 and 2 Ma is smaller compared to more northeastern African locations. More stable conditions during the PlioPleistocene compared to northern sites may have allowed southeast Africa to be a refuge for hominins and fauna during the early Pleistocene (e.g. Castañeda et al., 2016).

This article is protected by copyright. All rights reserved. 


\subsection{Mechanisms of regional hydroclimate variability}

\subsubsection{The Indian Ocean}

Indian Ocean SSTs are a critical control on East Africa hydroclimate (e.g. Tierney et al., 2008, 2013). In the Limpopo River catchment, SSTs of the nearby Agulhas Current (Figure 1) are known to strongly influence modern summer precipitation (e.g. Jury et al., 1993) and glacialinterglacial changes in vegetation cover (e.g. Dupont et al., 2011). Site U1478 biomarker records illustrate the role of Indian Ocean SSTs on hydroclimate in the Limpopo region during the PlioPleistocene, with high (low) SST excursions at the UAC corresponding to lower (higher) $\delta D_{\text {wax }}$ values, indicating reduced (increased) aridity and a land-sea linkage at the southeast African margin (Figure 2). Comparison of the $\mathrm{U} 1478 \delta \mathrm{D}_{\text {wax }}$ and $\mathrm{TEX}_{86}$ records demonstrates moderate covariance between hydroclimate and SSTs, with notable coherence in trends throughout the records, particularly after $\sim 3.1 \mathrm{Ma}$ (Figure 2). However, mismatches between $\mathrm{U} 1478 \delta \mathrm{D}_{\mathrm{wax}}$ and SSTs earlier in the mid-Pliocene (4-3.1 Ma) suggest the influence of additional controls on hydroclimate or $\delta \mathrm{D}_{\mathrm{wax}}$.

Zonal SST gradients across the Indian Ocean and related atmospheric patterns similar to the IOD could also play a role in hydroclimate variability. The IOD is a coupled oceanatmosphere climate phenomenon that modulates east African rainfall through its impact on equatorial easterlies, atmospheric convection, and monsoon strength (Abram et al., 2007; Schott et al., 2009). During positive IOD phases, increased eastern Indian Ocean equatorial upwelling decreases thermocline depth, resulting in reduced SSTs that correlate to anomalous equatorial easterly winds and increased precipitation in the warmer western Indian Ocean (Schott et al., 2009). To evaluate the influence of IOD-like conditions on Plio-Pleistocene southeast African precipitation patterns, we show Indian Ocean SST gradients by comparing our records to the TEX $_{86}$ SST reconstruction at Site U1463, located in the eastern subtropical Indian Ocean (Figures $1 b, 4)$. We use the cross-basin temperature difference between records $(\Delta \mathrm{SST})$ to illustrate Indian Ocean SST gradients that influence large-scale ocean-atmosphere patterns and interpret $\Delta \mathrm{SST}$ to reflect positive $(+\Delta \mathrm{SST})$ or negative (- $\Delta \mathrm{SST})$ IOD-like conditions (Figure 6). Site U1463 records SSTs off the western coast of Australia near the ITF outflow (Smith et al., 2020 ) and overlaps with the U1478 records from $~ 3.5-1.8 \mathrm{Ma}$ (Figure 4$)$. The $\Delta \mathrm{SST}_{\mathrm{U} 1478-\mathrm{U} 1463}$ record displays striking coherence with $\delta \mathrm{D}_{\text {wax }}$ from $\sim 3.5-2.9 \mathrm{Ma}$, with the exception of the abrupt increase in rainfall at 3.2 Ma (Figure 6). Overall, $\Delta \mathrm{SST}_{\mathrm{U} 1478-\mathrm{U} 1463}$ and $\delta \mathrm{D}_{\text {wax }}$ have a

This article is protected by copyright. All rights reserved. 
moderate correlation of $-0.36(\mathrm{p}<0.01)$. The $\Delta \mathrm{SST}_{\mathrm{U} 1478-\mathrm{U} 1463}$ record shows a notable decrease toward negative IOD-like conditions from 2.8-2.3 Ma and a subsequent increase toward positive IOD-like conditions between 2.3 and $1.8 \mathrm{Ma}$ (Figure 6).

The relationship between $\delta \mathrm{D}_{\text {wax }}$ and $\Delta \mathrm{SST}$ supports the importance of Indian Ocean zonal SST gradients in establishing IOD-like ocean-atmosphere interactions that likely modulated changes in rainfall through the mid-to-late Pliocene and into the early Pleistocene (Figure 6). The hydroclimate effects of positive IOD phases have a distinct meridional pattern (Goddard and Graham, 1999), with increased rainfall in northeastern Africa and increased aridity in southern Africa. Like Lake Malawi (Johnson et al., 2016), Site U1478 is near the boundary between these rainfall regimes delineated by the effects of the IOD. Tierney et al. (2013) describe the differing multidecadal and longer-term influence of SST gradients on interior and coastal locations in east Africa; as the western Indian Ocean warms, precipitation reductions in the Rift Valley and increases near the Horn of Africa and coastal regions are noted. The $\mathrm{U} 1478 \delta \mathrm{D}_{\text {wax }}$ and $\Delta \mathrm{SST}$ records suggest that stronger SSTs gradients, with warmer conditions in the western Indian Ocean, are accompanied by reduced aridity in the Limpopo catchment (Figure 6), more closely matching an equatorial and coastal east African response to a positive IOD. Notably, the $\Delta \mathrm{SST}_{\mathrm{U} 1478-\mathrm{U} 1463}$ record suggests negative IOD-like conditions in the Pliocene between 3.5 and 3.3 Ma that resolve some of the differences in trends between $\delta \mathrm{D}_{\text {wax }}$ and marginal SSTs. Reduced aridity during the mPWP also corresponds well with an increase in $\triangle \mathrm{SST}_{\mathrm{U1478-U1463}}$, indicating positive IOD-like conditions that likely acted in concert with relatively high marginal SSTs to enhance precipitation. Additionally, the onset of aridity in western Australia (Christensen et al., 2017) and wetter conditions in the Limpopo catchment coincides with an increase in $\triangle \mathrm{SST}_{\mathrm{U} 1478-\mathrm{U} 1463}$ between 2.35 and $1.8 \mathrm{Ma}$ (Figure 6). These cross-basin conditions are characteristic of IOD-like conditions, further supporting the control of SST gradients on early Pleistocene rainfall within the Limpopo catchment. In general, organic geochemical proxy evidence from Site U1478 and $\Delta$ SST reinforce the importance of the Indian Ocean in driving hydroclimate patterns in southeast Africa.

5.4.2 Glacial-interglacial variability and rain belt position

The significant obliquity signal throughout most of the $\mathrm{U} 1478 \delta \mathrm{D}_{\text {wax }}$ record suggests that glacial-interglacial variability and its effect on the position of the tropical rain belt also

This article is protected by copyright. All rights reserved. 
influenced hydroclimate during the Plio-Pleistocene. Obliquity induced fluctuations in high latitude ice sheet extent can force the tropical rain belt to migrate toward the Equator and reduce rainfall. This high latitude control is particularly evident at Site U1478 during the mid-Pliocene M2 and KM2 glacials, which coincide with more arid conditions in the Limpopo region, but relatively stable SSTs at the UAC. This likely reflects a northward migration of the tropical rain belt in response to increased ice extent in the Southern Hemisphere (Dolan et al., 2015; McKay et a., 2012) and illustrates the occasional absence of the predominant SST control on Limpopo hydroclimate. Additionally, Northern Hemisphere ice sheet advances can cause southward excursions of the tropical rain belt that contribute to precipitation increases in southeast Africa, as has been established for the Zambezi River catchment (Schefuß et al., 2011). This mechanism could help to explain Pliocene aridity in the Limpopo region despite high marginal SSTs and globally warmer conditions, as relatively reduced Northern Hemisphere ice sheet extent could have limited southward excursions of the tropical rain belt. Following the intensification of NHG around $2.7 \mathrm{Ma}$, the Limpopo region potentially received some rainfall from the southerly position of the tropical rain belt. Some of the most negative $\delta \mathrm{D}_{\text {wax }}$ values correspond to concurrent large increases in global ice volume following intensified NHG and high SSTs at Site U1478, such as at $2.5 \mathrm{Ma}$ and $2.1 \mathrm{Ma}$ (Figure 2). However, Northern Hemisphere forcing of the tropical rain belt is not the dominant hydroclimate control at Site U1478 during the early Pleistocene, as the onset of intensified NHG corresponds to overall more arid conditions between 2.8 and 2.2 Ma (Figure 2). High latitude glacial-interglacial variability and Indian Ocean dynamics were both likely determinants of southeast African rainfall, and differences in Northern Hemisphere ice sheet extent during the Plio-Pleistocene could have contributed to changes in hydroclimate.

\subsubsection{Variable Plio-Pleistocene hydroclimate controls}

Hydroclimate in the Limpopo region is influenced by multiple atmospheric, oceanic, and orbital processes that may operate differently through time. Caley et al. (2018) discuss runoff variability in the Limpopo catchment over the last $2 \mathrm{Ma}$ and allows for some evaluation of how hydroclimate controls may have changed across the Plio-Pleistocene. Caley et al. (2018) illustrate precession and eccentricity periodicities in $\ln (\mathrm{Fe} / \mathrm{Ca})$ data over the past $2 \mathrm{Ma}$ from core MD96-2048, suggesting a low-latitude insolation control on rainfall variability. As the

This article is protected by copyright. All rights reserved. 
Pleistocene SST record does not display a similar precession signal and instead primarily reflects glacial-interglacial variability, Caley et al. (2018) conclude that precipitation changes were not regulated by SSTs alone, and the land-sea temperature contrast was likely more important. These interpretations contrast some with Site U1478 records for the Pliocene and early Pleistocene, which demonstrate a clearer covariance between hydroclimate and SSTs. The Limpopo region is close to the modern boundary where the response to the IOD reverses (Goddard \& Graham, 1999), and fluctuation of this boundary through time could contribute to different hydroclimate signals (Johnson et al., 2016). Further investigation of Pleistocene ocean-atmosphere patterns similar to the IOD could aid in understanding comprehensive changes in hydroclimate in the Limpopo region and variable forcing mechanisms. Although $\delta D_{\text {wax }}$ at Site U1478 does not display a clear precession signal, this is likely related to sampling resolution, and the higher resolution $\mathrm{XRF} \log (\mathrm{Ti} / \mathrm{Ca})$ record of runoff does illustrate a dominant precession periodicity for the early Pleistocene (2.8-1.8 Ma) and late Pliocene (4-3.7 Ma) portions of our record (Koutsodendris et al., 2020). Overall, records from the Limpopo region over the last $4 \mathrm{Ma}$ illustrate similar mechanisms controlling rainfall, although their strength and expression appear to have varied through time.

\section{Conclusion}

Our new Site U1478 Plio-Pleistocene SST and $\delta D_{\text {wax }}$ records address a spatiotemporal gap in studies of East African paleoclimate and record the Limpopo River catchment response to large-scale climate changes. Cooling of $\sim 3.2^{\circ} \mathrm{C}$ between 3.7 and 3.2 Ma at Site U1478 suggest that ITF variability during the mid-Pliocene impacted SSTs at the UAC. Lower SSTs likely related to changes in the ITF were not accompanied by a pronounced trend towards increased aridity, although hydroclimate remained variable and overall arid conditions prevailed at this time. These cooler conditions correspond to increased Cyperaceae abundance, characteristic of glacial conditions, and reduced Poaceae grassland extent. The latter half of the mPWP in the Limpopo region is marked by an increase in warmer, wetter conditions between 3.2 and $3 \mathrm{Ma}$ that coincide with decreased Cyperaceae abundance. SSTs at the UAC were $\sim 2{ }^{\circ} \mathrm{C}$ higher than modern towards the end of the mPWP, and subsequently decrease by $3.6^{\circ} \mathrm{C}$ between 2.8 and 2.2 $\mathrm{Ma}$, corresponding to the intensification of NHG. Southeast Africa became cooler and drier 
during the Plio-Pleistocene and vegetation composition is characterized by an increase is Cyperaceae and relatively stable grassland extent.

Similarities between the $\delta \mathrm{D}_{\text {wax }}$ and TEX 86 records establish a link between continental hydroclimate and marginal SSTs, with notable covariance in the late Pliocene and early Pleistocene. SST gradients across the Indian Ocean, which influence atmospheric circulation and precipitation delivery to the Limpopo region, additionally contributed to hydroclimate variability in southeast Africa during the Plio-Pleistocene. Indian Ocean zonal $\Delta$ SST suggests that Pliocene aridity followed by wetter conditions during the mPWP may have been enhanced by IOD-like patterns and associated impacts on Walker circulation. The obliquity signal in $\delta \mathrm{D}_{\text {wax }}$ also indicates the importance of high latitude glacial-interglacial variability and its influence on the position of the tropical rain belt. It is likely that the behavior of the tropical rain belt varied through the Plio-Pleistocene in response to more intense NHG. Pliocene aridity in southeastern Africa coincident with high marginal SSTs might be explained by negative IOD-like conditions or a more northerly position of the tropical rain belt in the absence of extensive Northern Hemisphere ice sheets.

\section{Acknowledgements}

We would like to thank Drs. Dana Biasatti and Jeffrey Salacup for laboratory assistance. Thank you to the Center for Environmental Science and Technology (CEST) at the University of Notre Dame and the captain and crew of the Joides Resolution. This research was supported by a Clare Boothe Luce Fellowship (to MAB and AKT), the National Science Foundation Graduate Research Funding Program (GRFP) (to AKT), a Geological Society of America (GSA) Charles A. and June R.P. Ross Research Fund grant (to AKT), a U.S. Science Support Program PostExpedition Award (to MAB), and the Deutsche Forschungsgemeinschaft within the IODP Special Priority Program (grant KO4960/8 to AK). We appreciate the helpful comments and suggestions provided by two anonymous reviewers and the Associate Editor, Dr. Sarah Feakins, that improved this manuscript.

\section{Data Availability Statement}

Site U1478 data generated for this study is accessible through PANGAEA (https://doi.pangaea.de/10.1594/PANGAEA.923959). Data from other studies used for 
comparison include $\log (\mathrm{Ti} / \mathrm{Ca}$ ) from Koutsodendris et al., 2020 (IODP Site U1478), leaf wax isotopes and TEX 86 derived SubTs from Liddy et al., 2016 (DSDP Site 231), TEX 86 derived SSTs from Smith et al., 2020 (IODP Site U1463), and Mg/Ca derived SSTs from Karas et al., 2011 (ODP Site 763A).

\section{References}

Abram, N. J., Gagan, M. K., Liu, Z., Hantoro, W. S., McCulloch, M. T., \& Suwargadi, B. W. (2007). Seasonal characteristics of the Indian Ocean Dipole during the Holocene epoch. Nature, 445(7125), 299-302. https://doi.org/10.1038/nature05477

Anand, P., Elderfield, H., \& Conte, M. H. (2003). Calibration of $\mathrm{Mg} / \mathrm{Ca}$ thermometry in planktonic foraminifera from a sediment trap time series. Paleoceanography, 18(2). https://doi.org/10.1029/2002PA000846

Bamford, M. (1999). Pliocene Fossil Woods from an Early Hominid Cave Deposit, Sterkfontein, South Africa. South African Journal of Science, 95, 231-237.

Berke, M. A., Johnson, T. C., Werne, J. P., Grice, K., Schouten, S., \& Sinninghe Damsté, J. S. (2012). Molecular records of climate variability and vegetation response since the Late Pleistocene in the Lake Victoria basin, East Africa. Quaternary Science Reviews, 55, 59-74. https://doi.org/10.1016/j.quascirev.2012.08.014

Bobe, R., Behrensmeyer, A. K., \& Chapman, R. E. (2002). Faunal change, environmental variability and late Pliocene hominin evolution. Journal of Human Evolution, 42(4), 475-497. https://doi.org/10.1006/jhev.2001.0535

Boroto, R. A. J. (2001). Limpopo River: Steps towards sustainable and integrated water resources management. In Schumann, A. H., Acreman, M. C., Davis, R., Marino, M. A., Rosberg, D., and Jun, X. (Eds.), Regional Management of Water Resources (Vol. 268, pp. 33-39). Proceedings of the International Association of Hydrological Sciences.

Caley, T., Extier, T., Collins, J. A., Schefuß, E., Dupont, L., Malaizé, B., et al. (2018). A two-million-year-long hydroclimatic context for hominin evolution in southeastern Africa. Nature, 560(7716), 76-79. https://doi.org/10.1038/s41586-018-0309-6

This article is protected by copyright. All rights reserved. 
Cane, M. A., \& Molnar, P. (2001). Closing of the Indonesian seaway as a precursor to east African aridification around 3-4 million years ago. Nature, 411(6834), 157-162. https://doi.org/10.1038/35075500

Castañeda, I. S., Caley, T., Dupont, L., Kim, J.-H., Malaizé, B., \& Schouten, S. (2016). Middle to Late Pleistocene vegetation and climate change in subtropical southern East Africa. Earth and Planetary Science Letters, 450, 306-316. https://doi.org/10.1016/j.eps1.2016.06.049

Cerling, T., Wynn, J., Andanje, S., Bird, M., Korir, D., Levin, N., et al. (2011). Woody Cover and Hominin Environments in the Past 6 Million Years. Nature, 476, 51-6. https://doi.org/10.1038/nature10306

Cerling, T. E., Manthi, F. K., Mbua, E. N., Leakey, L. N., Leakey, M. G., Leakey, R. E., et al. (2013). Stable isotope-based diet reconstructions of Turkana Basin hominins. Proceedings of the National Academy of Sciences, 110(26), 10501. https://doi.org/10.1073/pnas.1222568110

Christensen, B. A., Renema, W., Henderiks, J., De Vleeschouwer, D., Groeneveld, J., Castañeda, I. S., et al. (2017). Indonesian Throughflow drove Australian climate from humid Pliocene to arid Pleistocene. Geophysical Research Letters, 44(13), 69146925. https://doi.org/10.1002/2017GL072977

Dansgaard, W. (1964). Stable isotopes in precipitation. Tellus, 16(4), 436-468. https://doi.org/10.1111/j.2153-3490.1964.tb00181.x

deMenocal, P. B. (1995). Plio-Pleistocene African Climate. Science, 270(5233), 53. https://doi.org/10.1126/science.270.5233.53

deMenocal, P. B. (2004). African climate change and faunal evolution during the PliocenePleistocene. Earth and Planetary Science Letters, 220(1), 3-24. https://doi.org/10.1016/S0012-821X(04)00003-2

Dolan, A. M., Haywood, A. M., Hunter, S. J., Tindall, J. C., Dowsett, H. J., Hill, D. J., \& Pickering, S. J. (2015). Modelling the enigmatic Late Pliocene Glacial Event Marine Isotope Stage M2. Global and Planetary Change, 128, 47-60. https://doi.org/10.1016/j.gloplacha.2015.02.001

This article is protected by copyright. All rights reserved. 
Dowsett, H., Dolan, A., Rowley, D., Moucha, R., Forte, A. M., Mitrovica, J. X., et al. (2016). The PRISM4 (mid-Piacenzian) paleoenvironmental reconstruction. Clim. Past, 12(7), 1519-1538. https://doi.org/10.5194/cp-12-1519-2016

Dupont, L. M., Caley, T., Kim, J.-H., Castañeda, I., Malaizé, B., \& Giraudeau, J. (2011). Glacial-interglacial vegetation dynamics in South Eastern Africa coupled to sea surface temperature variations in the Western Indian Ocean. Clim. Past, 7(4), 12091224. https://doi.org/10.5194/cp-7-1209-2011

Dupont, L., Caley, T., \& Castañeda, I. (2019). Effects of atmospheric CO2 variability of the past 800 kyr on the biomes of southeast Africa. Climate of the Past, 15, 1083-1097. https://doi.org/10.5194/cp-15-1083-2019

Fallet, U., Ullgren, J. E., Castañeda, I. S., van Aken, H. M., Schouten, S., Ridderinkhof, H., \& Brummer, G.-J. A. (2011). Contrasting variability in foraminiferal and organic paleotemperature proxies in sedimenting particles of the Mozambique Channel (SW Indian Ocean). Geochimica et Cosmochimica Acta, 75(20), 5834-5848. https://doi.org/10.1016/j.gca.2011.08.009

Fallet, U., Castañeda, I. S., Henry-Edwards, A., Richter, T. O., Boer, W., Schouten, S., \& Brummer, G.-J. (2012). Sedimentation and burial of organic and inorganic temperature proxies in the Mozambique Channel, SW Indian Ocean. Deep Sea Research Part I: Oceanographic Research Papers, 59, 37-53. https://doi.org/10.1016/j.dsr.2011.10.002

Feakins, S. J., deMenocal, P. B., \& Eglinton, T. I. (2005). Biomarker records of late Neogene changes in northeast African vegetation. Geology, 33(12), 977-980. https://doi.org/10.1130/G21814.1

Fedorov, A. V., Brierley, C. M., Lawrence, K. T., Liu, Z., Dekens, P. S., \& Ravelo, A. C. (2013). Patterns and mechanisms of early Pliocene warmth. Nature, 496(7443), 4349. https://doi.org/10.1038/nature12003

Goddard, L., \& Graham, N. E. (1999). Importance of the Indian Ocean for simulating rainfall anomalies over eastern and southern Africa. Journal of Geophysical Research: Atmospheres, 104(D16), 19099-19116. https://doi.org/10.1029/1999JD900326

Griepentrog, M., De Wispelaere, L., Bauters, M., Bodé, S., Hemp, A., Verschuren, D., \& Boeckx, P. (2019). Influence of plant growth form, habitat and season on leaf-wax n-

This article is protected by copyright. All rights reserved. 
alkane hydrogen-isotopic signatures in equatorial East Africa. Geochimica et Cosmochimica Acta, 263, 122-139. https://doi.org/10.1016/j.gca.2019.08.004

Hahn, A., Miller, C., Andó, S., Bouimetarhan, I., Cawthra, H. C., Garzanti, E., et al. (2018). The Provenance of Terrigenous Components in Marine Sediments Along the East Coast of Southern Africa. Geochemistry, Geophysics, Geosystems, 19(7), 1946-1962. https://doi.org/10.1029/2017GC007228

Hammer, O., Harper, D., \& Ryan, P. (2001). PAST: Paleontological Statistics Software Package for Education and Data Analysis. Palaeontologia Electronica, 4, 1-9.

Hall, I. R., Hemming, S. R., LeVay, L. J., Barker, S., Berke, M. A., Brentegani, L., et al. (2017). Site U1478. In South African Climates (Agulhas LGM Density Profile). Proceedings of the International Ocean Discovery Program, 361: College Station, TX (International Ocean Discovery Program) doi: 10.14379/iodp.proc.361.107.2017

Haug, G. H., \& Tiedemann, R. (1998). Effect of the formation of the Isthmus of Panama on Atlantic Ocean thermohaline circulation. Nature, 393(6686), 673-676. https://doi.org/10.1038/31447

Haywood, A. M., Dowsett, H. J., \& Dolan, A. M. (2016). Integrating geological archives and climate models for the mid-Pliocene warm period. Nature Communications, 7(1), 10646. https://doi.org/10.1038/ncomms 10646

Herbert, T. D., Peterson, L. C., Lawrence, K. T., \& Liu, Z. (2010). Tropical Ocean Temperatures Over the Past 3.5 Million Years. Science, 328(5985), 1530. https://doi.org/10.1126/science.1185435

Herries, A. I. R., Pickering, R., Adams, J. W., Curnoe, D., Warr, G., Latham, A. G., \& Shaw, J. (2013). A Multi-Disciplinary Perspective on the Age of Australopithecus in Southern Africa. In K. E. Reed, J. G. Fleagle, \& R. E. Leakey (Eds.), The Paleobiology of Australopithecus (pp. 21-40). Dordrecht: Springer Netherlands. https://doi.org/10.1007/978-94-007-5919-0_3

Herries, A. I. R., Martin, J. M., Leece, A. B., Adams, J. W., Boschian, G., Joannes-Boyau, R., et al. (2020). Contemporaneity of Australopithecus, Paranthropus, and early Homo erectus in South Africa. Science, 368(6486), eaaw7293. https://doi.org/10.1126/science.aaw7293

This article is protected by copyright. All rights reserved. 
Herrmann, N., Boom, A., Carr, A. S., Chase, B. M., West, A. G., Zabel, M., \& Schefuß, E. (2017). Hydrogen isotope fractionation of leaf wax n-alkanes in southern African soils. Organic Geochemistry, 109, 1-13. https://doi.org/10.1016/j.orggeochem.2017.03.008

Hopmans, E. C., Weijers, J. W. H., Schefuß, E., Herfort, L., Sinninghe Damsté, J. S., \& Schouten, S. (2004). A novel proxy for terrestrial organic matter in sediments based on branched and isoprenoid tetraether lipids. Earth and Planetary Science Letters, 224(1), 107-116. https://doi.org/10.1016/j.epsl.2004.05.012

Hopmans, E. C., Schouten, S., \& Sinninghe Damsté, J. S. (2016). The effect of improved chromatography on GDGT-based palaeoproxies. Organic Geochemistry, 93, 1-6. https://doi.org/10.1016/j.orggeochem.2015.12.006

Huang, Y., Shuman, B., Wang, Y., \& Webb, T. (2004). Hydrogen isotope ratios of individual lipids in lake sediments as novel tracers of climatic and environmental change: a surface sediment test. Journal of Paleolimnology, 31(3), 363-375. https://doi.org/10.1023/B:JOPL.0000021855.80535.13

Hurley, S. J., Lipp, J. S., Close, H. G., Hinrichs, K.-U., \& Pearson, A. (2018). Distribution and export of isoprenoid tetraether lipids in suspended particulate matter from the water column of the Western Atlantic Ocean. Organic Geochemistry, 116, 90-102. https://doi.org/10.1016/j.orggeochem.2017.11.010

Inglis, G. N., Farnsworth, A., Lunt, D., Foster, G. L., Hollis, C. J., Pagani, M., et al. (2015). Descent toward the Icehouse: Eocene sea surface cooling inferred from GDGT distributions. Paleoceanography, 30(7), 1000-1020. https://doi.org/10.1002/2014PA002723

Johnson, T. C., Werne, J. P., Brown, E. T., Abbott, A., Berke, M., Steinman, B. A., et al. (2016). A progressively wetter climate in southern East Africa over the past 1.3 million years. Nature, 537(7619), 220-224. https://doi.org/10.1038/nature19065

Jury, M. R., Valentine, H. R., \& Lutjeharms, J. R. E. (1993). Influence of the Agulhas Current on Summer Rainfall along the Southeast Coast of South Africa. Journal of Applied Meteorology, 32(7), 1282-1287. https://doi.org/10.1175/15200450(1993)032<1282:IOTACO>2.0.CO;2

This article is protected by copyright. All rights reserved. 
Karas, C., Nürnberg, D., Tiedemann, R., \& Garbe-Schönberg, D. (2011). Pliocene Indonesian Throughflow and Leeuwin Current dynamics: Implications for Indian Ocean polar heat flux. Paleoceanography, 26(2). https://doi.org/10.1029/2010PA001949

Kim, J.-H., van der Meer, J., Schouten, S., Helmke, P., Willmott, V., Sangiorgi, F., et al. (2010). New indices and calibrations derived from the distribution of crenarchaeal isoprenoid tetraether lipids: Implications for past sea surface temperature reconstructions. Geochimica et Cosmochimica Acta, 74(16), 4639-4654. https://doi.org/10.1016/j.gca.2010.05.027

Konecky, B. L., Russell, J. M., Johnson, T. C., Brown, E. T., Berke, M. A., Werne, J. P., \& Huang, Y. (2011). Atmospheric circulation patterns during late Pleistocene climate changes at Lake Malawi, Africa. Earth and Planetary Science Letters, 312(3), 318326. https://doi.org/10.1016/j.eps1.2011.10.020

Koutsodendris, A., Nakajima, K., Kaboth-Bahr, S., Berke, M. A., Franzese, A. M., Hall, I. R., et al. (2020). A Plio-Pleistocene (c. 0-4 Ma) cyclostratigraphy for IODP Site U1478 (Mozambique Channel, SW Indian Ocean): Exploring an offshore record of paleoclimate and ecosystem variability in SE Africa. Newsletters on Stratigraphy. doi:10.1127/nos/2020/0608

Liddy, H. M., Feakins, S. J., \& Tierney, J. E. (2016). Cooling and drying in northeast Africa across the Pliocene. Earth and Planetary Science Letters, 449, 430-438. https://doi.org/10.1016/j.eps1.2016.05.005

Lisiecki, L. E., \& Raymo, M. E. (2005). A Pliocene-Pleistocene stack of 57 globally distributed benthic $\delta 180$ records. Paleoceanography, 20(1). https://doi.org/10.1029/2004PA001071

Lupien, R. L., Russell, J. M., Yost, C. L., Kingston, J. D., Deino, A. L., Logan, J., et al. (in press). Vegetation change in the Baringo Basin, East Africa across the onset of Northern Hemisphere glaciation 3.3-2.6 Ma. Palaeogeography, Palaeoclimatology, Palaeoecology, 109426. https://doi.org/10.1016/j.palaeo.2019.109426

Lutjeharms, J.R.E. (2006). The Agulhas Current. Springer-Verlag, Berlin. Maslin, M. A. \& Trauth, M. H. (2009). Plio-Pleistocene East African Pulsed Climate Variability and Its Influence on Early Human Evolution. In Grine, F. E., Fleagle, J.

This article is protected by copyright. All rights reserved. 
G., Leakey, R. E. (Eds.), The First Humans: Origin and Early Evolution of the Genus Homo. Vertebrate Paleobiology and Paleoanthropology (pp. 151-158). Springer, Dordrecht. doi:10.1007/978-1-4020-9980-9_13.

Maslin, M. A., Brierley, C. M., Milner, A. M., Shultz, S., Trauth, M. H., \& Wilson, K. E. (2014). East African climate pulses and early human evolution. Quaternary Science Reviews, 101, 1-17. https://doi.org/10.1016/j.quascirev.2014.06.012

McClymont, E. L., Ford, H. L., Ho, S. L., Tindall, J. C., Haywood, A. M., Alonso-Garcia, M., et al. (2020). Lessons from a high-CO2 world: an ocean view from $\sim 3$ million years ago. Clim. Past, 16(4), 1599-1615. https://doi.org/10.5194/cp-16-1599-2020

McKay, R., Naish, T., Carter, L., Riesselman, C., Dunbar, R., Sjunneskog, C., et al. (2012). Antarctic and Southern Ocean influences on Late Pliocene global cooling.

Proceedings of the National Academy of Sciences, 109(17), 6423.

https://doi.org/10.1073/pnas.1112248109

Nicholson, S. E. (2018). The ITCZ and the Seasonal Cycle over Equatorial Africa. Bulletin of the American Meteorological Society, 99(2), 337-348. https://doi.org/10.1175/BAMS-D-16-0287.1

Petrick, B., Martínez-García, A., Auer, G., Reuning, L., Auderset, A., Deik, H., et al. (2019). Glacial Indonesian Throughflow weakening across the Mid-Pleistocene Climatic Transition. Scientific Reports, 9(1), 16995. https://doi.org/10.1038/s41598-019$53382-0$

R Core Team (2020). R: A Language and Environment for Statistical Computing. R Foundation for Statistical Computing, Vienna, Austria.

Ravelo, A. C., Andreasen, D. H., Lyle, M., Olivarez Lyle, A., \& Wara, M. W. (2004).

Regional climate shifts caused by gradual global cooling in the Pliocene epoch.

Nature, 429(6989), 263-267. https://doi.org/10.1038/nature02567

Reason, C. J. C., \& Mulenga, H. (1999). Relationships between South African rainfall and SST anomalies in the Southwest Indian Ocean. International Journal of Climatology, 19(15), 1651-1673. https://doi.org/10.1002/(SICI)1097-

0088(199912)19:15<1651::AID-JOC439>3.0.CO;2-U

This article is protected by copyright. All rights reserved. 
Rozanski, K., Araguás-Araguás, L., \& Gonfiantini, R. (1992). Isotopic patterns in Global Precipitation. Journal of Geophysical Research, 78. https://doi.org/10.1029/GM078p0001

Sachse, D., Radke, J., \& Gleixner, G. (2004). Hydrogen isotope ratios of recent lacustrine sedimentary n-alkanes record modern climate variability. Geochimica et Cosmochimica Acta, 68(23), 4877-4889. https://doi.org/10.1016/j.gca.2004.06.004 Schefuß, E., Kuhlmann, H., Mollenhauer, G., Prange, M., \& Pätzold, J. (2011). Forcing of wet phases in southeast Africa over the past 17,000 years. Nature, 480(7378), 509512. https://doi.org/10.1038/nature10685

Schott, F. A., Xie, S.-P., \& McCreary Jr., J. P. (2009). Indian Ocean circulation and climate variability. Reviews of Geophysics, 47(1). https://doi.org/10.1029/2007RG000245

Schouten, S., Hopmans, E. C., Schefuß, E., \& Sinninghe-Damste, J. (2003). Distributional variations in marine crenarchaeotal membrane lipids: a new tool for reconstructing ancient sea water temperatures? Earth and Planetary Science Letters, 204, 265-274. https://doi.org/10.1016/S0012-821X(02)00979-2

Schulz, M., \& Mudelsee, M. (2002). REDFIT: Estimating red-noise spectra directly from unevenly spaced paleoclimatic time series. Computers \& Geosciences, 28, 421-426. https://doi.org/10.1016/S0098-3004(01)00044-9

Sinninghe Damsté, J. S., Ossebaar, J., Schouten, S., \& Verschuren, D. (2012). Distribution of tetraether lipids in the 25-ka sedimentary record of Lake Challa: extracting reliable TEX86 and MBT/CBT palaeotemperatures from an equatorial African lake.

Quaternary Science Reviews, 50, 43-54. https://doi.org/10.1016/j.quascirev.2012.07.001

Smith, R. A., Castañeda, I. S., Groeneveld, J., De Vleeschouwer, D., Henderiks, J., Christensen, B. A., et al. (2020). Plio-Pleistocene Indonesian Throughflow Variability Drove Eastern Indian Ocean Sea Surface Temperatures. Paleoceanography and Paleoclimatology, 35(10), e2020PA003872. https://doi.org/10.1029/2020PA003872

Taylor, K. W. R., Huber, M., Hollis, C. J., Hernandez-Sanchez, M. T., \& Pancost, R. D. (2013). Re-evaluating modern and Palaeogene GDGT distributions: Implications for SST reconstructions. Global and Planetary Change, 108, 158-174. https://doi.org/10.1016/j.gloplacha.2013.06.011

This article is protected by copyright. All rights reserved. 
Tierney, J. E., Russell, J. M., Huang, Y., Damsté, J. S. S., Hopmans, E. C., \& Cohen, A. S. (2008). Northern Hemisphere Controls on Tropical Southeast African Climate During the Past 60,000 Years. Science, 322(5899), 252. https://doi.org/10.1126/science.1160485

Tierney, J. E., Smerdon, J. E., Anchukaitis, K. J., \& Seager, R. (2013). Multidecadal variability in East African hydroclimate controlled by the Indian Ocean. Nature, 493, 389.

Tierney, J. E., \& Tingley, M. P. (2014). A Bayesian, spatially-varying calibration model for the TEX86 proxy. Geochimica et Cosmochimica Acta, 127, 83-106. https://doi.org/10.1016/j.gca.2013.11.026

Tierney, J. E., \& Tingley, M. P. (2015). A TEX86 surface sediment database and extended Bayesian calibration. Scientific Data, 2, 150029.

Tyson, P.D. \& Preston-Whyte, R.A. (2000). The weather and climate of Southern Africa. Cape Town, South Africa: Oxford University Press Southern Africa.

Weijers, J. W. H., Schouten, S., Hopmans, E. C., Geenevasen, J. A. J., David, O. R. P., Coleman, J. M., et al. (2006). Membrane lipids of mesophilic anaerobic bacteria thriving in peats have typical archaeal traits. Environmental Microbiology, 8(4), 648657. https://doi.org/10.1111/j.1462-2920.2005.00941.x

Zhang, Y. G., Zhang, C. L., Liu, X.-L., Li, L., Hinrichs, K.-U., \& Noakes, J. E. (2011). Methane Index: A tetraether archaeal lipid biomarker indicator for detecting the instability of marine gas hydrates. Earth and Planetary Science Letters, 307(3), 525534. https://doi.org/10.1016/j.epsl.2011.05.031

Zhao, X., Koutsodendris, A., Caley, T., \& Dupont, L. (2020). Hydroclimate change in subtropical South Africa during the mid-Piacenzian Warm Period. Quaternary Science Reviews, 249, 106643. https://doi.org/10.1016/j.quascirev.2020.106643

Figure 1. (a) Location of Site IODP U1478 in relation to the Agulhas Current (AC), Agulhas Leakage (AL), Agulhas Return Current (ARC), Madagascar Current (MC), South East Madagascar Current (SEMC), South Equatorial Current (SEC), North East Madagascar Current (NEMC), the Congo Air Boundary (CAB), and the tropical rain belt, known as the Intertropical Convergence Zone (ITCZ) over the ocean. The Limpopo River catchment is also outlined. (b) Map of referenced study sites in eastern Africa and the Indian Ocean including DSDP Site 231 (Liddy et al., 2016), HSPDP BTB13 (Lupien et al., in press), the Lake Malawi MAL05-1 drill

This article is protected by copyright. All rights reserved. 
core (Johnson et al., 2016), IODP Site U1463 (Smith et al., 2020), and ODP Site 763A (Karas et al., 2011). Indian Ocean currents referenced in text, including the Indonesian Throughflow (ITF) and Leeuwin Current (LC), are additionally indicated.

Figure 2. Plio-Pleistocene comparison between (a) the $\delta^{18} \mathrm{O}$ benthic stack record (Lisiecki \& Raymo, 2005), illustrating changes in global ice volume, and Site U1478 proxy records. Site U1478 data include (b) TEX 86 derived SST $\left({ }^{\circ} \mathrm{C}\right),(\mathrm{c}) \delta \mathrm{D}_{\text {wax }}(\%$ o), with error bars representing the standard deviation of duplicate analyses, (d) the BIT index, and (e) XRF-based $\log (\mathrm{Ti} / \mathrm{Ca}$ ) (Koutsodendris et al., 2020). Changes associated with the switch in Indonesian Throughflow, mid-Pliocene Warm Period (mPWP), Marine Isotope Stages M2 and KM2, and the intensification of Northern Hemisphere glaciation are labelled.

Figure 3. Site U1478 biomarker records of (a) hydroclimate $\left(\delta \mathrm{D}_{\mathrm{wax}}, \%\right.$ o $)$ and (b) inversed SST $\left({ }^{\circ} \mathrm{C}\right)$ for comparison to pollen. Pollen relative abundances $(\%)$ of common taxa include (c) Cyperaceae, (d) Poaceae, (e) Podocarpus, (f) Asteraceae, (g) Buxus sp., and (h) Ericaceae.

Figure 4. Plio-Pleistocene water temperature records from the Indian Ocean. We compare TEX 86 derived temperatures at (a) Site U1478 in the southwest Indian Ocean (SST; this study), (b) DSDP Site 231 in the Gulf of Aden (SubT; Liddy et al., 2016), and (c) Site U1463 near the outflow of the Indonesian Throughflow (SST; Smith et al., 2020). We also include (d) the $\mathrm{Mg} / \mathrm{Ca}$ derived SST record from ODP Site 763A (Karas et al., 2011) in the southeast Indian Ocean for comparison. Changes associated with the switch in Indonesian Throughflow, mid-Pliocene Warm Period (mPWP), and the intensification of Northern Hemisphere glaciation are labelled.

Figure 5. Compound-specific isotope records from leaf waxes illustrating climate and environmental change in East Africa during the Plio-Pleistocene. The $\delta \mathrm{D}_{\text {wax }}$ values (\%o) display (a) hydroclimate variability in southeastern (Site U1478, this study) and (b) northeastern (DSDP Site 231, Liddy et al., 2016) Africa. (c) Compound-specific carbon isotopes $\left(\delta^{13} \mathrm{C}_{\mathrm{wax}}, \%\right.$ ) show changes in $\mathrm{C}_{3}$ vs. $\mathrm{C}_{4}$ vegetation from DSDP Site 231 (Liddy et al., 2016).

Figure 6. Cross basin comparison of Indian Ocean SSTs, presented as the $\Delta$ SST between Site U1478 and Site U1463 (Smith et al., 2020), compared to hydroclimate at Site U1478 $\left(\delta \mathrm{D}_{\mathrm{wax}}, \%\right.$, in black). We interpret $\Delta \mathrm{SST}$ as a proxy for ocean-atmosphere patterns similar to the Indian Ocean Dipole (IOD), where relatively warmer conditions in the western Indian Ocean define positive IOD-like conditions. Increased precipitation, resulting from a higher $\Delta \mathrm{SST}$, is likely driven onto land via enhanced easterly winds.

This article is protected by copyright. All rights reserved. 

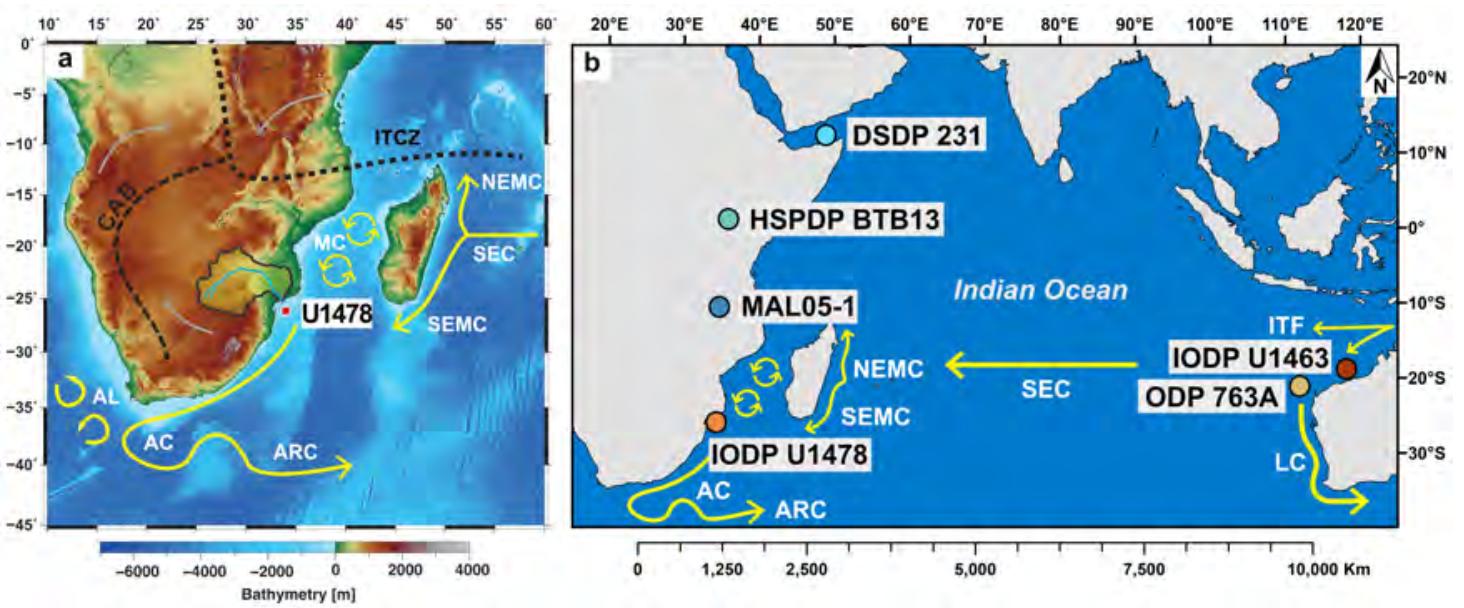

This article is protected by copyright. All rights reserved. 


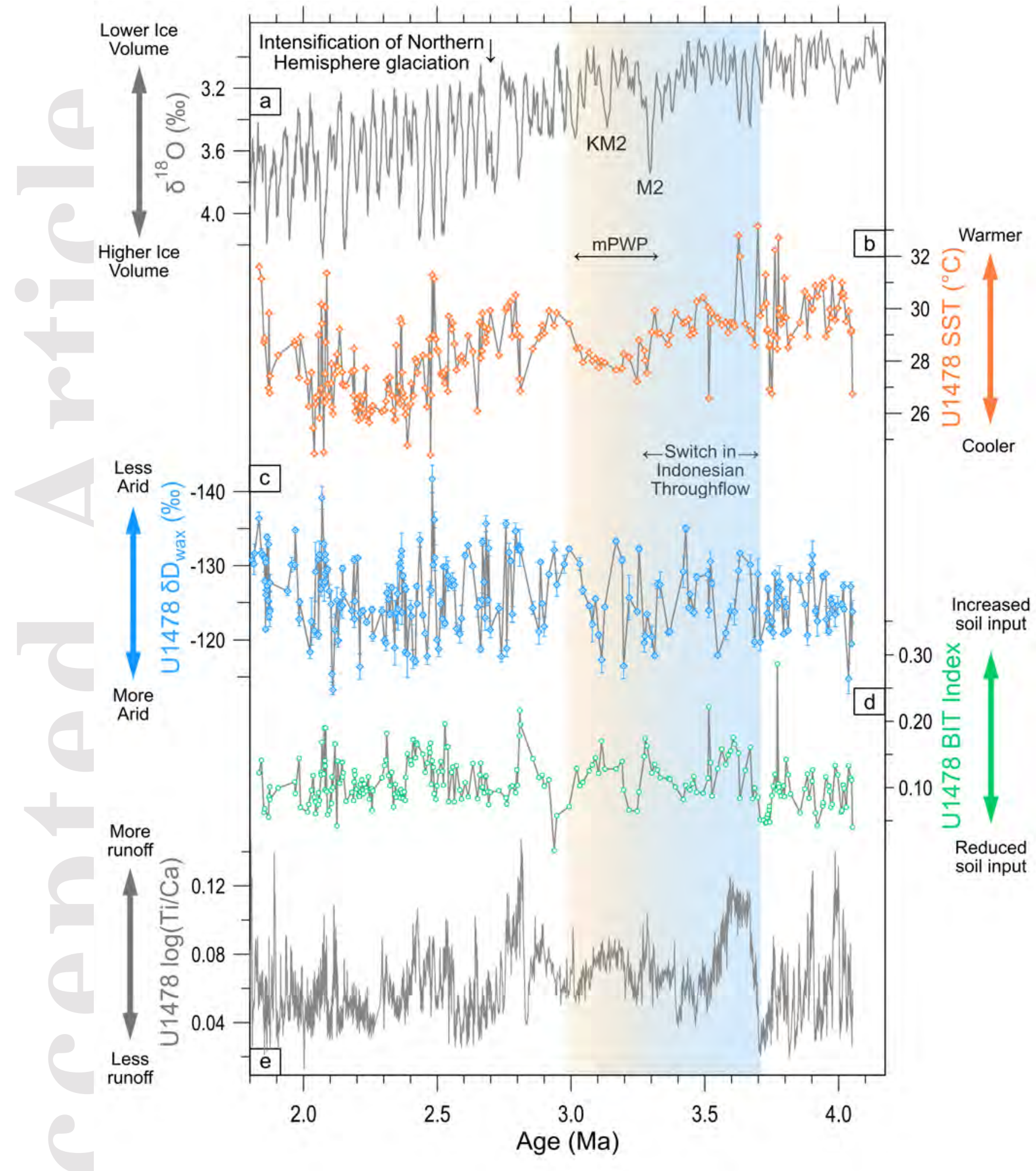

This article is protected by copyright. All rights reserved. 


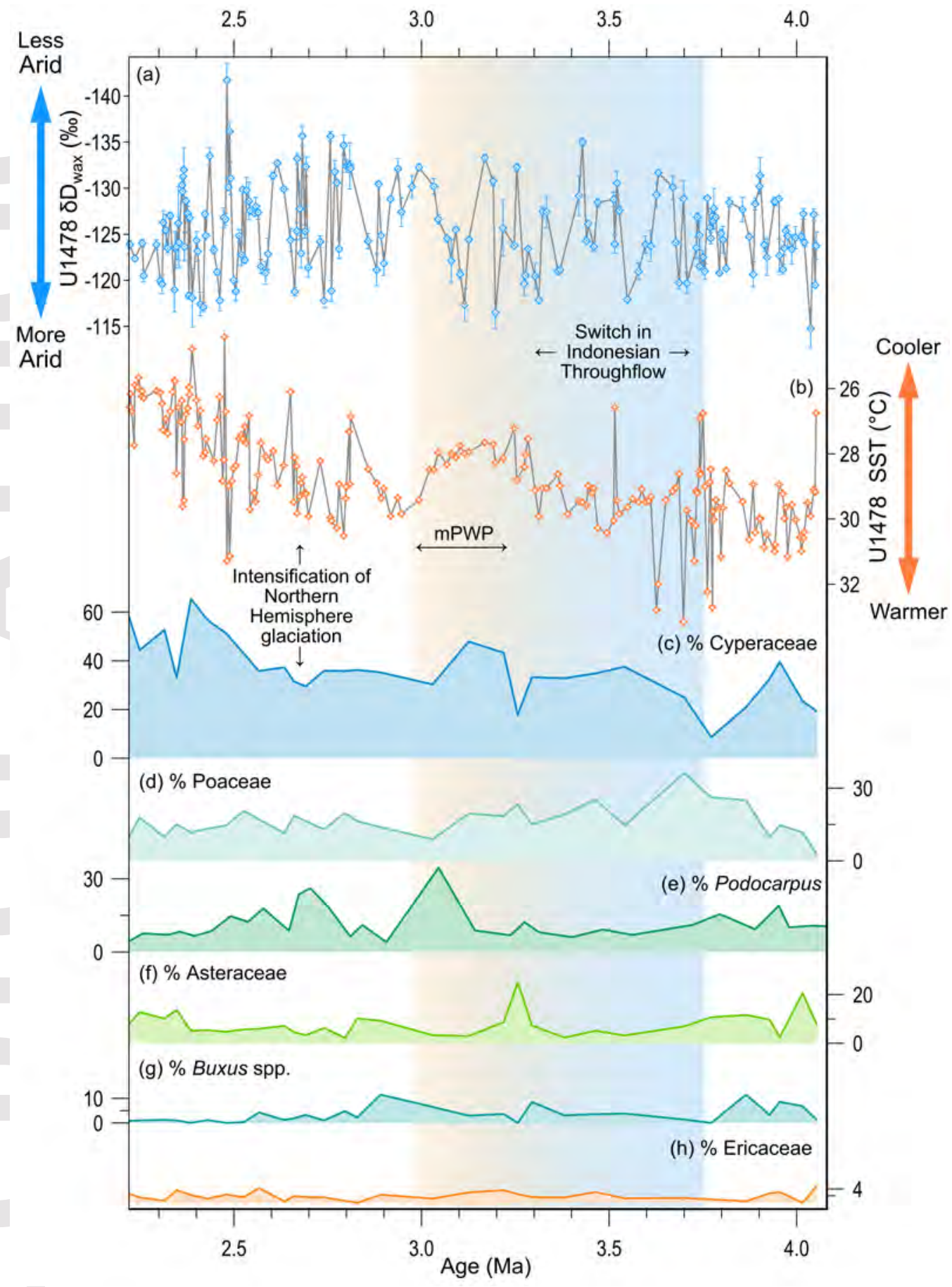

This article is protected by copyright. All rights reserved. 


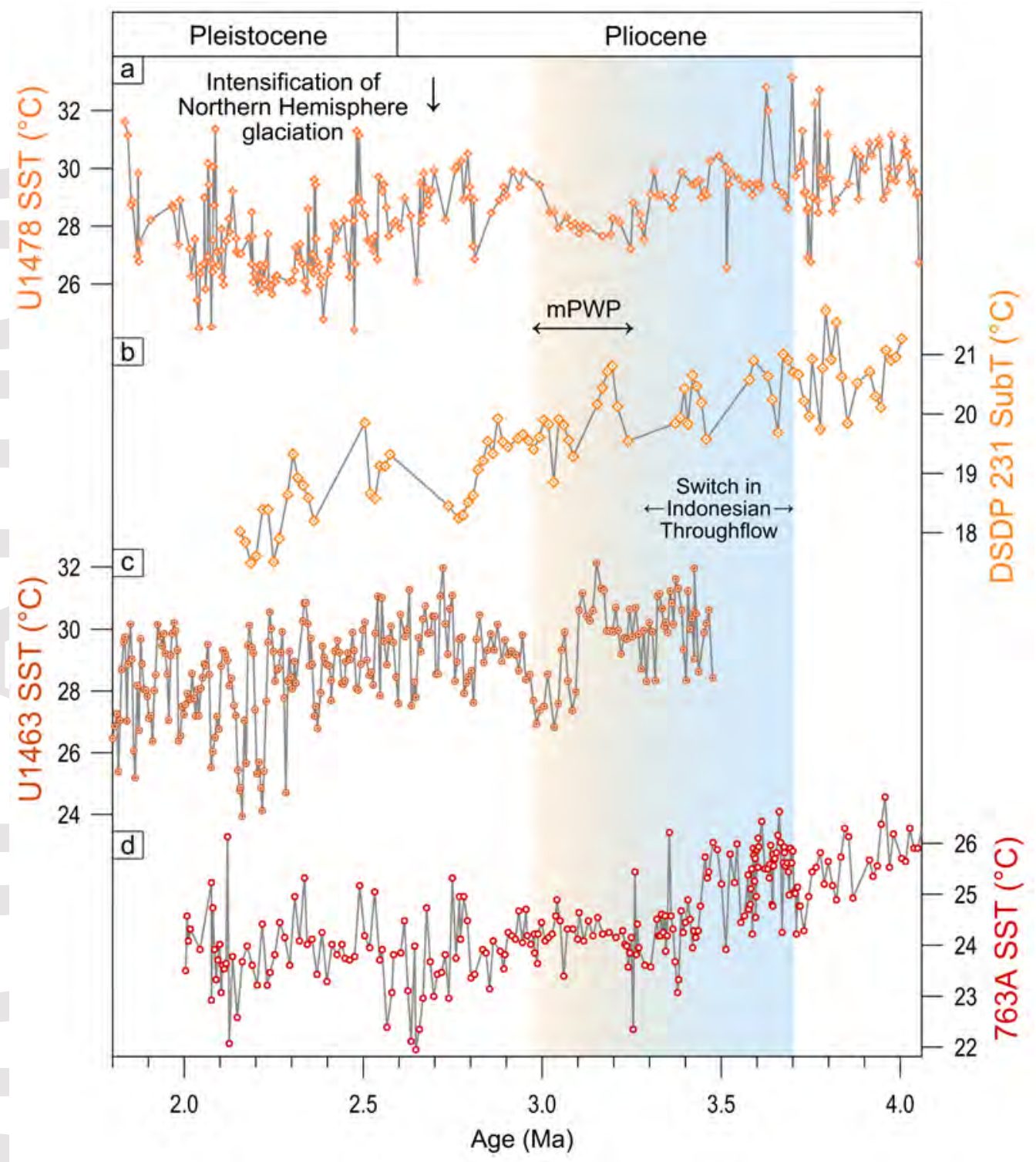

This article is protected by copyright. All rights reserved. 


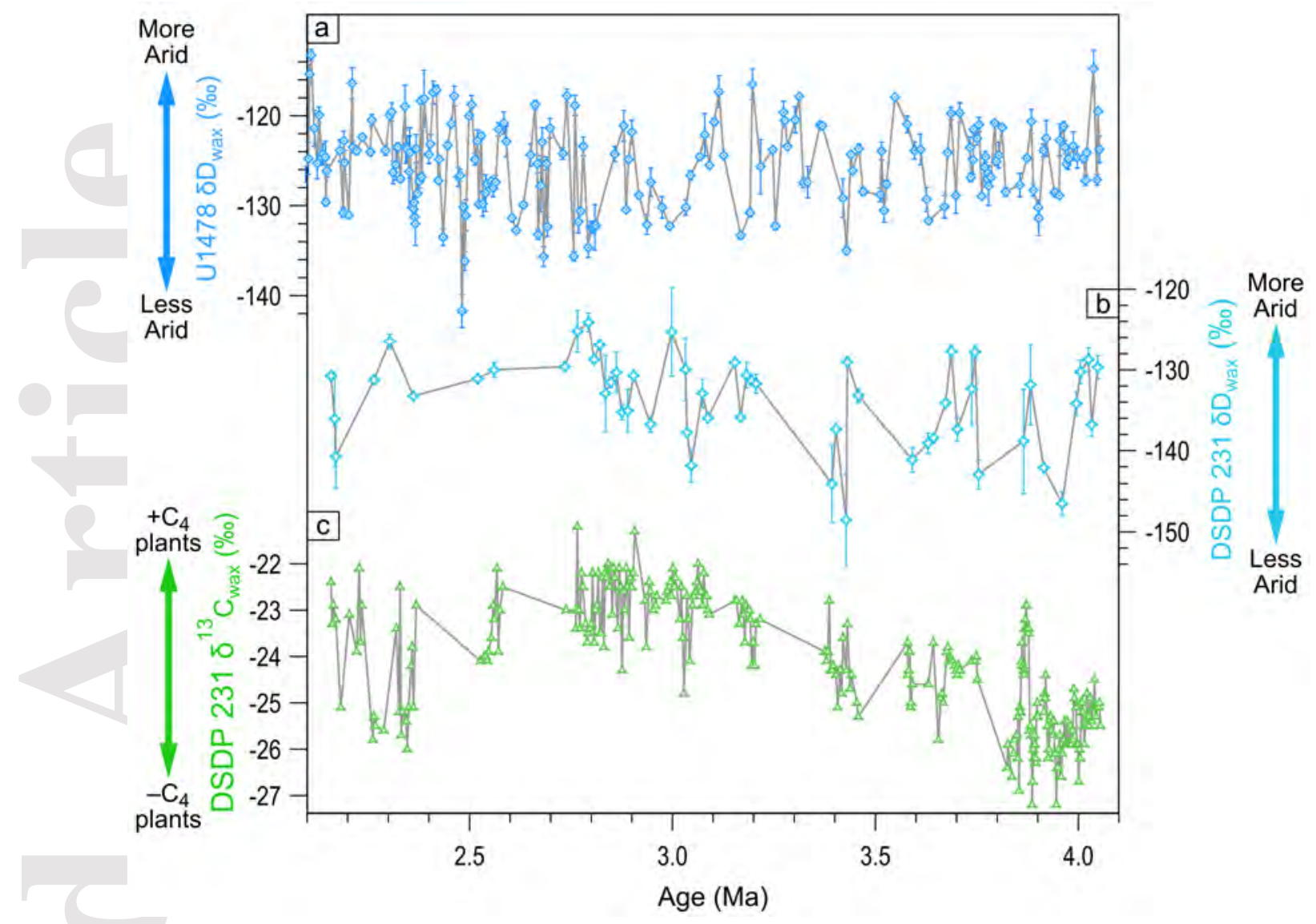

This article is protected by copyright. All rights reserved. 


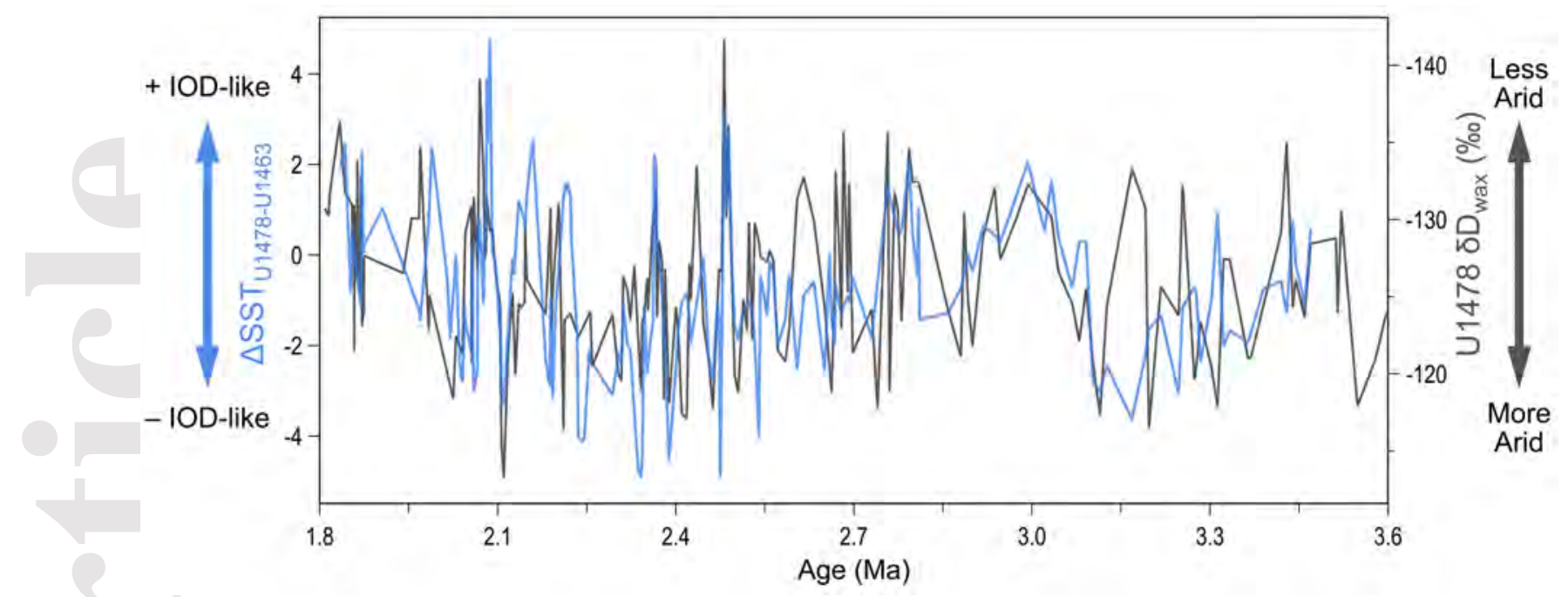

This article is protected by copyright. All rights reserved. 